\title{
Production Networks and Trade Patterns in East Asia: Regionalization or Globalization?*
}

\author{
Prema-chandra \\ Athukorala \\ Arndt-Corden Department of \\ Economics \\ Crawford School of Economics \\ and Government \\ College of Asia and The Pacific \\ Australian National University \\ prema- \\ chandra.athukorala@anu.edu.au
}

\begin{abstract}
This paper examines the implications of global production sharing for economic integration in East Asia with emphasis on the behavior of trade flows in the wake of the 2008 global financial crisis. Although trade in parts and components and final assembly within production networks ("network trade") has generally grown faster than total world trade in manufacturing, the degree of dependence of East Asia on this new form of international specialization is proportionately larger than elsewhere in the world. Network trade has certainly strengthened economic interdependence among countries in the region with the People's Republic of China playing a pivotal role as the premier center of final assembly. However, contrary to popular belief, this has not lessened the dependence of the export dynamism of these countries on the global economy. This inference is basically consistent with the behavior of trade flows following the onset of the global financial crisis.
\end{abstract}

\section{Introduction}

Global production sharing-the break-up of the production process into geographically separated stages-has been an increasingly important facet of economic globalization over the past four decades. ${ }^{1}$ With a modest start in

* The author is grateful to Waltraut Urban (Vienna Institute for International Economic Studies), Myunghun Lee (Inha University), Shigeyuki Abe (Doshisha University), and other participants of the Asian Economic Panel meeting, Seoul, 22-23 March 2010, for helpful comments on the first draft of the paper.

1 The term production sharing was coined by Drucker (1977). In the recent literature an array of alternative terms have been 
the electronics and clothing industries, multinational production networks have gradually evolved and spread into many industries such as sports footwear, automobiles, televisions and radio receivers, sewing machines, office equipment, power and machine tools, cameras and watches, and printing and publishing. At the formative stage, the production sharing involved locating small fragments of the production process in a low-cost country and re-importing the assembled parts and components to be incorporated in the final product. Subsequently, production networks began to encompass many countries engaged in the assembly process at different stages, resulting in multiple border crossings by product fragments before they were incorporated in the final product. As international networks of parts and component supply have become firmly established, producers in advanced countries have begun to move the final assembly of an increasing range of consumer durables (e.g., computers, cameras, television sets, and automobiles) to overseas locations to be physically closer to their final users and/or take advantage of cheap labor (Brown and Linden 2005; Feenstra 2008).

Global production sharing opens up opportunities for countries to specialize in different slices (tasks) of the production process depending on their relative cost advantage and other relevant economic fundamentals. In this context, the decisions regarding how much to produce and for which target market are combined with decisions on where to produce and with what degree of intra-product specialization. Consequently, trade flow analysis based on data coming from a reporting system designed at a time when countries were trading predominantly only in final goods naturally distorted values of exports and imports, leading to a falsification of the nature of emerging trade patterns. The degree of falsification is likely to increase over time as more complex production networks are created with an ever-increasing number of participants.

This paper examines the size and dynamics of global production sharing and network trade in East Asia with special emphasis on the regional and global integration of countries in the region. There is clear evidence that global production sharing has strengthened economic interdependence among countries in East Asia, with the People's Republic of China (PRC) playing a pivotal role as the premier center of final assembly. However, contrary to popular belief, this has not lessened the dependence of these countries on the global economy; the dynamism of this new form of international exchange depends inexorably on extra-regional demand for final goods. This inference is basically consistent with the behavior of trade flows following the onset of the global financial crisis.

used to describe this phenomenon, including international production fragmentation, vertical specialization, slicing the value chain, and outsourcing. 
The paper is organized as follows. Section 2 discusses the procedure followed in extracting data from the United Nations (UN) trade data tapes and data quality. Section 3 examines the nature and extent of global network trade and the role of East Asian countries in this new global division of labor. Section 4 deals with the implications of this new form of international exchange for intra-regional trade and for creating new supply-side complementariness among countries in the region, with emphasis on the emerging role of the PRC in regional production networks. In Section 5, the latest available data are pieced together to examine the role of network trade in determining the impact of the global crisis on the export performance of East Asian economies. The main findings are summarized in Section 6.

\section{Data}

Previous studies have used two alternative approaches to quantifying the magnitude and pattern of trade taking place within global production networks (network trade). ${ }^{2}$ The first approach relies on records kept by OECD countries (in particular the United States and the European Union [EU]) in connection with special tariff provisions on overseas processing and the assembly of domestically produced components (outward processing trade [OPT] statistics) (Helleiner 1973; Sharpton 1975; USITC 1999; Gorg 2000). OPT records provide data on parts and components exported from source countries and assembled goods received in turn. However, the OPT schemes only cover a limited range of products, and the actual product coverage has varied significantly, both within and among countries over time. Perhaps more importantly, recent trends in unilateral trade and investment liberalization, and the proliferation of bilateral and regional economic integration agreements, have significantly reduced the importance of such tariff concessions in promoting global sourcing and, therefore, the actual utilization of these schemes. Moreover, by their very nature, these administrative records leave out cross-border transitions among third countries within global production networks.

The second approach, pioneered by Yeats (2001) and pursued in a number of recent studies (Ng and Yeats 2003; Athukorala 2005; Kimura 2006; Athukorala and Yamashita 2008), involves delineating trade in parts and components by using individual country trade statistics extracted from the UN trade data reporting system

2 A number of recent studies have used imported input content of industrial production, estimated using input-output tables, to measure the growth of global production sharing in world trade at the industry/country level. Growth in the measured degree of importedinput dependence between two time points is interpreted as an indicator of the growth of global production sharing (Hummels, Ishii, and Yi 2001; Dean, Fung, and Wang 2007). This approach is not relevant for the present study, which aims to examine the patterns and determinants of production-sharing-driven trade flows. 
(Comtrade database). This approach provides comprehensive and consistent coverage of the parts and components trade encompassing a large number of countries. This approach suffers from two major limitations, however. First, the commodity coverage is limited to parts and components, which can be directly identifiable based on the commodity nomenclature of the U.S. Standard International Trade Classification (SITC) system. These items are confined to the product classes of machinery and transport equipment (SITC 7 and SITC 8). However, there is evidence that global production sharing has been spreading beyond SITCs 7 and 8 to other product categories, such as machine tools and various metal products (belonging to SITC 6). Second, and more importantly, even if we ignore the problem of under coverage, parts and components are only one of the facets of network trade. As noted at the outset, there has been a remarkable expansion of network activities from pure component production and assembly to final assembly. Moreover, the relative importance of these two tasks varies among countries and over time in a given country, making it problematic to use data on the parts and components trade as a general indicator of the trends and evolving patterns of network trade over time and across countries.

The analysis in this paper makes use of data extracted from the U.S. trade data system following a procedure that aims to redress these two limitations to the extent permitted by the nature of data availability. We use a list of parts and components encompassing the entire spectrum of manufacturing trade. The list was compiled by mapping parts and components in the UN Broad Economic Classification (BEC) Registry ${ }^{3}$ in the product list of the World Trade Organization Information Technology Agreement with the Harmonize System (HS) of trade classification at the sixdigit level. Information gathered from firm-level surveys conducted in Thailand and Malaysia was used to fill gaps in the list. ${ }^{4}$ Data compiled at the HS 6-digit level were converted to SITC for the final analysis using the UN HS-SITC concordance.

There is no hard and fast rule applicable to distinguishing between parts and components and assembled products in international trade data. The only practical way of doing this is to focus on the specific product categories in which network trade is heavily concentrated. Once these product categories have been identified, assembly trade can be approximately estimated as the difference between parts and components—directly identified based on our list—and recorded trade in these

3 The BEC registry can be found at www.unstats.un.org/unsd/cr/registry.

4 The list of parts and components is given in the Appendix in the discussion paper version of this paper (Athukorala 2010). Total value of parts and components enumerated for the period 1992-2007 based on this list is on average 52 percent higher compared to the value based on the incomplete list used in Athukorala (2005). 
product categories. Guided by the available literature on production sharing, we identified seven product categories: office machines and automatic data processing machines (SITC 75), telecommunication and sound recording equipment (SITC 76), electrical machinery (SITC 77), road vehicles (SITC 78), professional and scientific equipment (SITC 87), and photographic apparatus (SITC 88). It is quite reasonable to assume that these product categories contain virtually no products produced from start to finish in a given country. However, admittedly the estimates based on this list do not provide full coverage of final assembly in world trade. For instance, outsourcing of final assembly does take place in various miscellaneous product categories such as clothing, furniture, sporting goods, and leather products. However, it is not possible to meaningfully delineate parts and components and assembled goods in reported trade in these product categories because they contain a significant (yet unknown) share of horizontal trade. Likewise, assembly activities in software trade have recorded impressive expansion in recent years, but these are lumped together in the UN data system with "special transactions" under SITC 9. However, the magnitude of the bias resulting from the failure to cover these items is unlikely to be substantial because network trade in final assembly is heavily concentrated in the product categories covered in our decomposition (Yeats 2001; Krugman 2008).

Regarding country coverage, Asia is defined to encompass the economies of East Asia, including the newly industrialized economies of the Republic of Korea (Korea); Taiwan and Hong Kong (China); the PRC; and selected members of the Association of Southeast Asian Nations (ASEAN). Among the ASEAN countries, only the six largest economies-Indonesia, Malaysia, the Philippines, Thailand, Singapore, and Vietnam-are covered in the statistical analysis. Brunei, Cambodia, Lao People's Democratic Republic (Lao PDR), and Myanmar are excluded because of data limitations. The East Asian experience is examined in the wider global context, focusing on the region's performance relative to the NAFTA and the EU.

The data are tabulated using importer records, which are considered to be more appropriate for analyzing trade patterns than the corresponding exporter records. Compared to country records, importer records are also presumably less susceptible to double-counting and erroneous identification of the source/destination country in the presence of entrepot trade (e.g., the PRC's trade through Hong Kong and Indonesia's trade through Singapore) (Feenstra et al. 1999; Ng and Yeats 2003). Some countries also fail to properly report goods shipped from their own export-processing zones as these tend to be grouped into one highly aggregated category of "special transactions" under SITC 9. It is difficult to find a satisfactory solution for these problems. However, it is generally believed that data compiled from importer 
records are less susceptible to recording errors and reveal the origin and composition of trade more accurately than other records because there are normally important legal penalties for incorrectly specifying this information on customs declarations. Data for Taiwan, which is not covered in the UN data system, are obtained from the trade database (based on the same classification system) of the Council for Economic Planning and Development, Taipei. The analysis covers 1992 to 2007. We selected 1992 as the starting point because by this time countries accounting for over 95 percent of total world manufacturing trade had adopted the revised data reporting system. Meanwhile, 2007 was the most recent year for which data were available for all reporting countries.

\section{East Asia in global production networks}

Rapid export growth has been the hallmark of East Asia's rise in the global economy. The combined share of East Asian countries in world non-oil exports recorded a three-fold increase, from 11 percent to 33 percent, between 1969-70 and 2006-07. ${ }^{5}$ The region accounted for over 40 percent of the total increase in world exports over this period. In the 1970s and 1980s, Japan dominated the region's trade, accounting for nearly 60 percent of exports and imports. The picture has changed dramatically over the past two decades with the share of developing East Asian countries increasing rapidly in the face of a relative decline in Japan's position in world trade. By 2006-07, these countries accounted for over 80 percent of total regional trade. The rise of the PRC has been the dominant factor behind this structural shift, but other countries in the region-Taiwan, Korea, and ASEAN-have also increased their world market shares.

Rapid export growth in East Asia has been underpinned by a pronounced shift in export structure away from primary commodities and toward manufacturing. By 2006-07, manufacturing accounted for 92 percent of total exports from Asia, up from 78 percent four decades earlier. Manufacturing, machinery, and transport equipment (SITC 7)—especially information and communication technology (ICT) products and electrical goods-have played a pivotal role in this structural shift. The share of Asia in world machinery and transport equipment exports increased from 14.5 percent in 1994-95 to 42.4 percent in 2006-07, with emerging East Asia accounting for over 80 percent of the increment. By 2006-07, over 58 percent of total world ICT ex-

5 Trade magnitudes throughout the paper are measured in current U.S. dollars unless otherwise indicated. Inter-temporal comparison calculations are made for the two-year averages relating to the end points of the period under study, so as to reduce the impact of year-toyear fluctuations of trade flows. All data reported, unless otherwise stated, are compiled from the UN Comtrade database. 
ports originated from Asia, with the PRC alone accounting for 23 percent. In electrical goods, the PRC's world market share increased from 3.1 percent to 20.6 percent between 1994-95 and 2006-07. As we explain subsequently, export dynamism in these product lines has been driven by the ongoing process of global production sharing and the increasingly deep integration of East Asian countries into global production networks.

Table 1 presents data on world trade based on global production sharing (network trade) and East Asia's relative position in this new international exchange. World network trade increased from US\$ 1,207 billion (about 23.8 percent of total exports) in 1992-93 to US\$ 4,525 billion (45.5 percent) in 2006-07, accounting for over a half of the total increment in world manufacturing exports during this period. There has been a palpable shift in global production sharing away from mature industrial economies toward developing countries and in particular toward East Asia. The share of developing countries in total network exports increased from 22.0 percent in 1992-93 to 45.7 percent in 2005-06, driven primarily by the growing importance of East Asian countries in global production sharing (Figure 1). The share of East Asia (including Japan) increased from 32.2 percent in 1992-93 to 40.3 percent in 2006-07, despite a notable decline in Japan's share, from 18.4 percent to 9.5 percent. The major driving force has been the PRC, whose share increased from 2.1 percent to 14.5 percent. Within East Asia, world market shares of ASEAN countries, with the exception of Singapore, have grown faster than the regional average. The mild decline in Singapore's share reflects a marked shift in its role in global production networks for high-tech industries away from the standard assembly and testing activities to oversight functions, product design, and capital and technology-intensive tasks in the production process. Some, if not most, of these new activities are in the form of services and are, therefore, not captured in merchandise trade data (Wong 2007; Athukorala 2008).

Between 1992-93 and 2006-07, there has been a sharp increase in the share of parts and components in network trade across all countries in the region (Table 1, last column). In all countries except the PRC and Thailand parts and components accounted for well over half of total network export (and imports) by 2006-07. The share of parts and components is particularly high among ASEAN countries. There is a remarkable similarity in parts and components share on the export and import sides across countries, reflecting overlapping specialization patterns in component assembly and testing among countries in the region.

Data on the composition of network trade are summarized by major country groups in Table 2. A striking feature of network trade in East Asia is its heavy concentration 


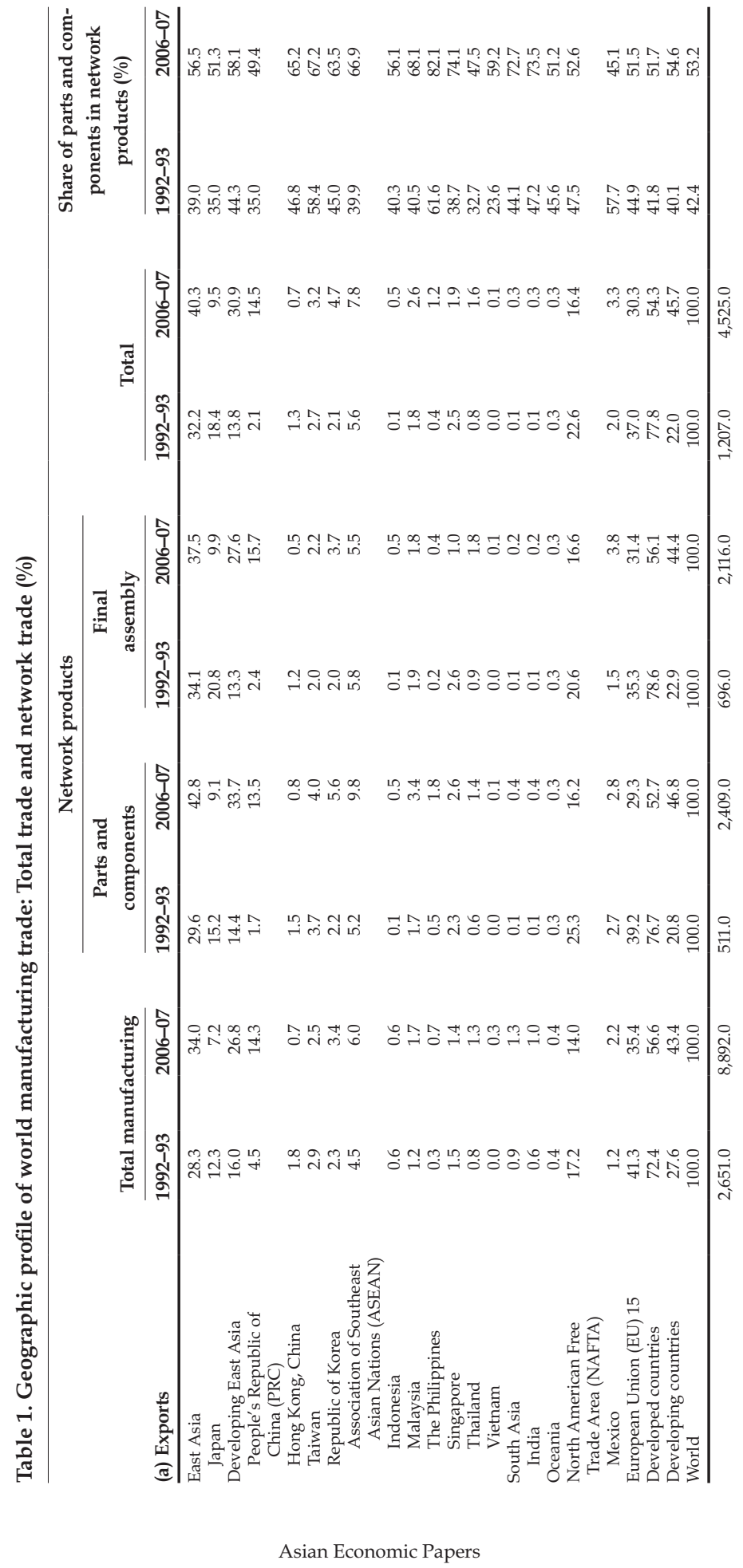




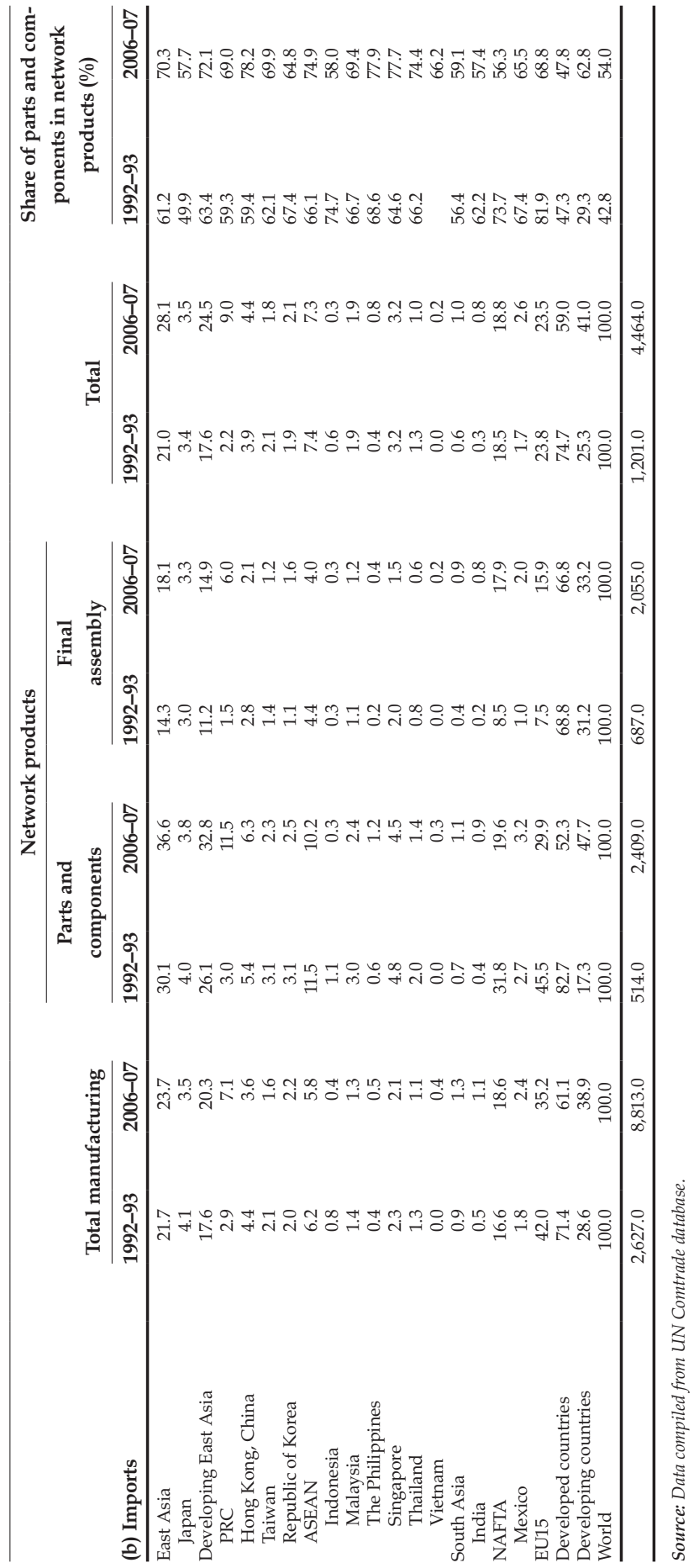


Figure 1. East Asia in world network trade: Share in world exports by country groups (\%)

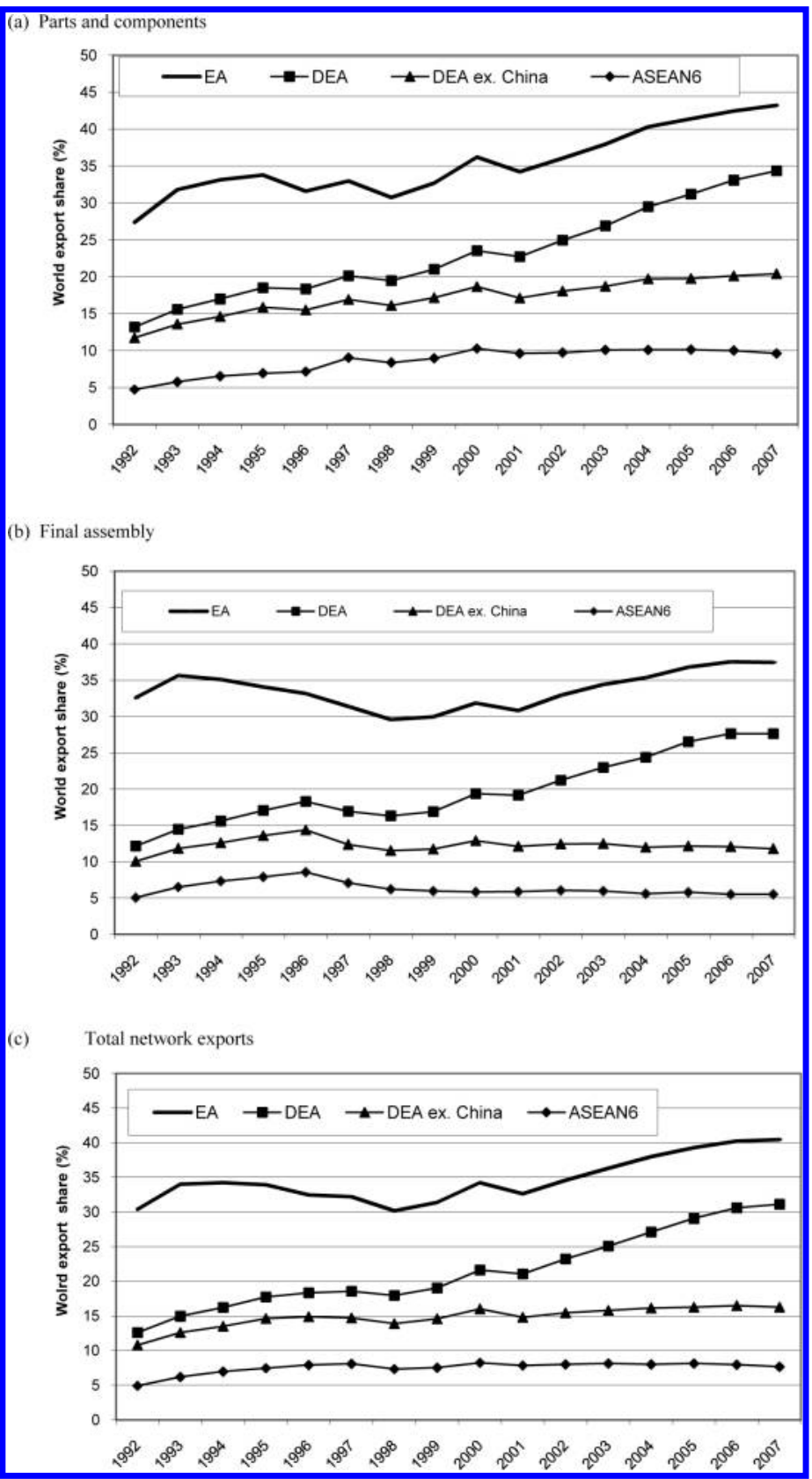

Source: Based on data compiled from a UN Comtrade database. 
Table 2. Share of network products in manufacturing trade, 1992-93 and 2006-07 (\%)

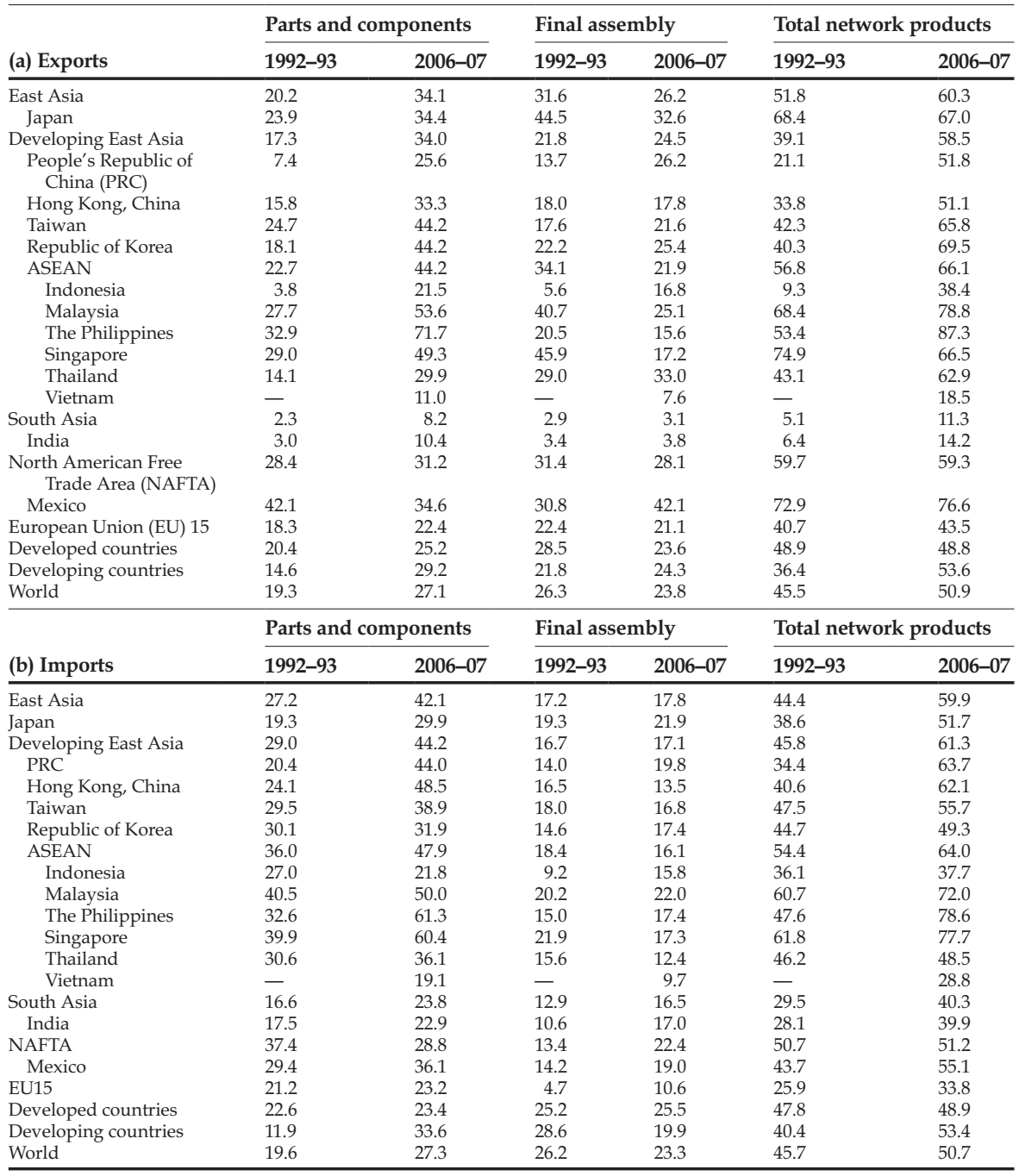

Source: Compiled from UN Comtrade database.

Note: $-=$ data not available.

in electrical machinery-in particular, semiconductor devices. In all countries and regions, component trade is heavily concentrated in the machinery and transport equipment sector (SITC 7). This commodity group accounts for over 90 percent of the combined component trade. Within SITC 7, both component exports and imports of East Asia are heavily concentrated in electronics and electrical industries. Semiconductors and other electronic parts and components (parts and components 
within SITC 77) alone accounted for 50 percent of component exports from East Asia in 2006-07. Adding parts and components of telecommunication equipment (SITC 76) and office and automated data processing machines (SITC 75) to these items increases the concentration ratio to almost 90 percent of the total exports of parts and components. The balance consists largely of electrical machinery (SITC 77) and auto parts (SITC 78). The concentration of component trade on electronics is much larger in the ASEAN Free Trade Area (over 60 percent) compared to the regional average. Electronics and electrical products are also major areas of activity in other countries and regions. However, the trade patterns of these countries and regions are characterized by a significant presence of other items, in particular, automotive parts and components (parts and components of motor vehicles, SITC 78, and other transport equipment, SITC 79). For instance, parts and components of these two product categories accounted for a mere 4.7 percent of total component exports in developing East Asia (DEA) in 2005-06 compared to over one-third in NAFTA and the EU. Moreover, unlike in NAFTA and the EU15, ${ }^{6}$ shares of parts and components in East Asian automobile imports are much higher compared to exports. This asymmetry is an indication of East Asia's relatively low level of participation in network trade.

The relatively low levels of network trade in automobile and transport equipment in East Asian countries cannot be explained in terms of their competitive edge in electronics and electrical industries alone. The total trade figures behind these export shares show that export growth in these products during 1992-2007 was much slower (a mere 5 percent in current U.S. dollars) compared to over 20 percent in NAFTA and over 15 percent in the EU.

There are two possible reasons for this contrast that deserve further study. First, in most East Asian countries, binding content protection requirements for the domestic production of automotives and tariffs on final products (usually implemented sideby-side with low or zero tariffs on parts and components) remained relatively high until recently (Abrenica 1998). Tariff protection and content protection requirements usually lead to more parts and components being produced domestically. They also tend to retard exports not only because of the incentive bias against exports, but also because domestic market-oriented production usually does not achieve the quality standards and cost competitiveness required for export success. Second, unlike electronics and electrical industries, parts and components in the automotive industry ${ }^{7}$

6 The EU15 comprises the following 15 countries: Austria, Belgium, Denmark, Finland, France, Germany, Greece, Ireland, Italy, Luxembourg, Netherlands, Portugal, Spain, Sweden, United Kingdom.

7 Air shipping is the mode of transport for over two-thirds of electronics exports from Singapore, the Philippines, Thailand, and Malaysia (estimate based on U.S. Trade Commission data on trade by mode of transport between 2000 and 2005). 
are generally characterized by low value-to-weight ratios, which make it too costly to use air transport for timely delivery (Hummels 2007). This could well be an important consideration for locating parts and component production-assembly plants close to the final assembly plants within automobile production networks. The data in Table 3 indicate a heavy concentration of international trade in automotive parts and components within NAFTA and the EU compared to East Asia and other regions (Klier and Rubenstine 2008, chapter 13).

Table 3 presents comparative statistics on the share of network trade in total manufacturing exports and imports at the country and country group levels. It is evident that the share of network trade is much higher in East Asia than in all other regions of the world. In 2006-07, exports within production networks accounted for over 60.3 percent of total manufacturing trade in East Asia, compared to the world average of 50.9 percent. Within East Asia, ASEAN countries stand out for their heavy dependence on production fragmentation trade, which is a critical part of their export dynamism. In 2006-07, production network exports accounted for 66 percent of total manufacturing exports in ASEAN, up from 56.8 percent in 1992-93. The patterns observed on the export and import sides of ASEAN are strikingly similar, reflecting growing cross-border trade within production networks.

\section{I China in East Asia trade}

Manufacturing products dominate China-East Asian trade flows, accounting for nearly 90 percent of both imports and exports (Table 4). In China's total manufacturing imports from East Asia, the share of parts and components increased from 18 percent in 1994-95 to over 44 percent in 2006-07. Within manufacturing, the share of parts and components is much larger in machinery and transport equipment imports, at nearly three-quarters in 2006-07. The shares of parts and components in manufacturing exports also have increased over the years, but the magnitudes are significantly lower compared to those in total imports. Interestingly, although China's importance as a market for the rest of East Asia has increased during the period under study (see the subsquent discussion), the importance of the region for China's export expansion has declined notably, as it only absorbed 33.7 percent of China's total merchandise exports in 2006-07, down from 55.8 percent in 1993. East Asia's share in China's total imports increased marginally from 21.3 percent in 199293 to 28.8 percent in 2006-07.

A comparison of the data on the share of parts and components in total exports and imports (Figure 2) highlights an important difference between the PRC and its East Asian neighbors: the share of parts and components in its total manufacturing imports is much larger compared to the corresponding share in its manufacturing 


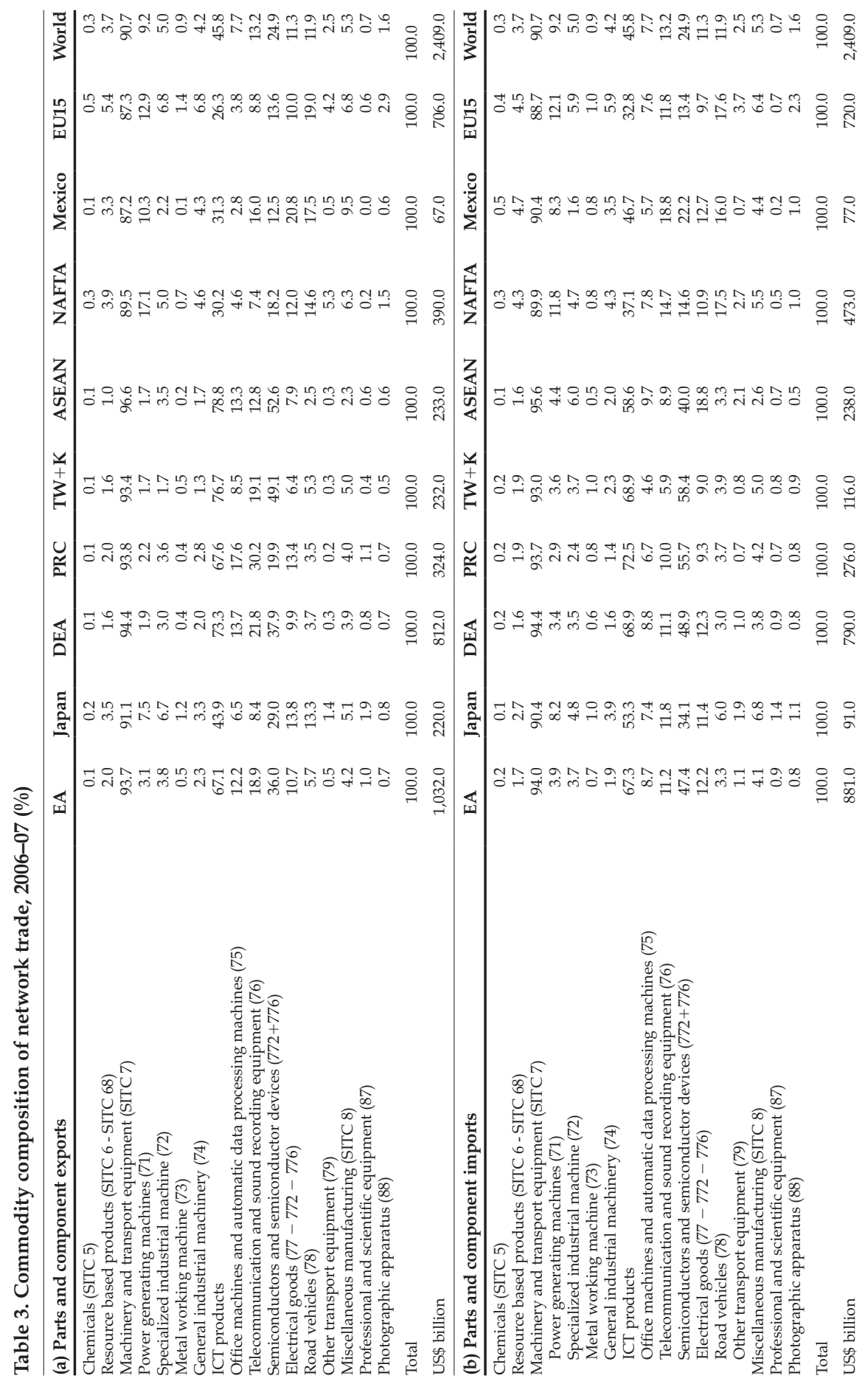




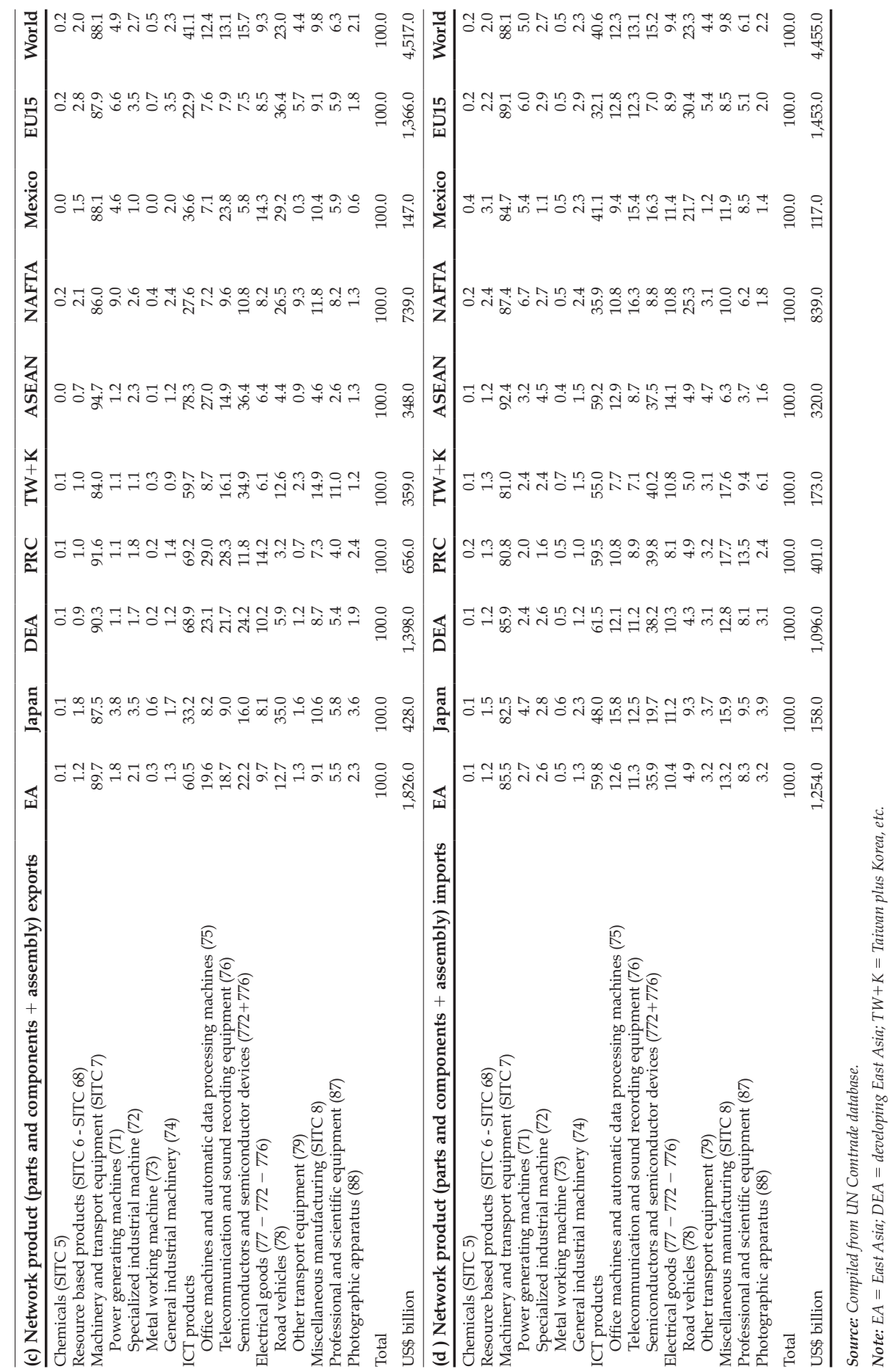


Table 4. China's trade with the rest of East Asia (\%)

\begin{tabular}{|c|c|c|c|c|}
\hline \multirow[b]{2}{*}{ A: Commodity composition } & \multicolumn{2}{|c|}{ Exports } & \multicolumn{2}{|c|}{ Imports } \\
\hline & 1994-95 & $2006-07$ & 1994-95 & $2006-07$ \\
\hline $\begin{array}{l}\text { A:1: Total trade } \\
\text { Primary products } \\
\text { Manufacturing } \\
\text { Machinery and transport equipment (SITC 7) } \\
\text { Electronics and electrical goods ( } 75+76+77 \text { ) } \\
\text { Miscellaneous manufacturing (SITC 8) } \\
\text { Apparel (84) }\end{array}$ & $\begin{array}{r}100.0 \\
16.2 \\
83.4 \\
20.8 \\
16.7 \\
43.3 \\
18.5\end{array}$ & $\begin{array}{r}100.0 \\
10.4 \\
89.2 \\
46.6 \\
40.6 \\
25.5 \\
10.3\end{array}$ & $\begin{array}{r}100.0 \\
23.5 \\
76.1 \\
26.4 \\
15.0 \\
7.7 \\
1.3\end{array}$ & $\begin{array}{r}100.0 \\
13.5 \\
86.3 \\
49.7 \\
43.0 \\
12.5 \\
0.4\end{array}$ \\
\hline $\begin{array}{l}\text { A2: Parts and components } \\
\text { Machinery and transport equipment (SITC 7) } \\
\text { Electronic and electrical goods }(75+76+77) \\
\text { Transport equipment (78) } \\
\text { Other }\end{array}$ & $\begin{array}{r}100.0 \\
90.2 \\
81.0 \\
3.7 \\
9.8\end{array}$ & $\begin{array}{r}100.0 \\
95.5 \\
87.7 \\
2.3 \\
4.5\end{array}$ & $\begin{array}{r}100.0 \\
92.1 \\
74.6 \\
0.7 \\
3.8\end{array}$ & $\begin{array}{r}100.0 \\
95.1 \\
85.7 \\
1.8 \\
3.3\end{array}$ \\
\hline \multicolumn{5}{|c|}{ B: Parts and component share in manufacturing trade } \\
\hline $\begin{array}{l}\text { Total manufacturing } \\
\text { Machinery and transport equipment (SITC 7) } \\
\text { Electronic and electrical goods }(75+76+77) \\
\text { Transport equipment } \\
\text { Other }\end{array}$ & $\begin{array}{r}7.5 \\
6.8 \\
30.3 \\
25.4 \\
1.4\end{array}$ & $\begin{array}{r}25.6 \\
24.4 \\
49.3 \\
50.1 \\
4.0\end{array}$ & $\begin{array}{l}17.9 \\
46.1 \\
73.1 \\
16.3 \\
18.0\end{array}$ & $\begin{array}{l}44.4 \\
73.3 \\
82.5 \\
79.0 \\
14.4\end{array}$ \\
\hline \multicolumn{5}{|l|}{ C: Trade with East Asia in China's world trade } \\
\hline $\begin{array}{l}\text { C.1: Total trade } \\
\text { Primary products } \\
\text { Manufacturing } \\
\text { Machinery and transport equipment (SITC 7) } \\
\text { Electronic and electrical goods (75176177) } \\
\text { Miscellaneous manufacturing (SITC 8) } \\
\text { Apparel (84) }\end{array}$ & $\begin{array}{l}55.8 \\
74.6 \\
53.3 \\
53.7 \\
60.4 \\
50.1 \\
59.1\end{array}$ & $\begin{array}{l}33.7 \\
59.2 \\
32.2 \\
33.1 \\
34.6 \\
29.1 \\
38.1\end{array}$ & $\begin{array}{l}21.3 \\
27.9 \\
19.9 \\
13.4 \\
53.0 \\
27.2 \\
45.1\end{array}$ & $\begin{array}{l}28.4 \\
15.5 \\
32.7 \\
32.0 \\
52.0 \\
36.0 \\
52.9\end{array}$ \\
\hline $\begin{array}{l}\text { C2: Parts and component } \\
\text { Machinery and transport equipment (SITC 7) } \\
\text { Electronic and electrical goods }(75+76+77) \\
\text { Transport equipment } \\
\text { Miscellaneous manufacturing (SITC 8) }\end{array}$ & $\begin{array}{l}60.1 \\
59.8 \\
61.2 \\
44.2 \\
62.2\end{array}$ & $\begin{array}{l}44.7 \\
44.6 \\
46.0 \\
23.2 \\
45.7\end{array}$ & $\begin{array}{r}22.4 \\
21.7 \\
68.9 \\
5.6 \\
30.3\end{array}$ & $\begin{array}{l}38.7 \\
38.6 \\
56.2 \\
21.7 \\
40.7\end{array}$ \\
\hline
\end{tabular}

Source: Compiled from UN Comtrade database.

Note: In this table, East Asia = Developing East Asia and Japan.

exports (44.0 percent and 25.6 percent, respectively, in 2006-07). Moreover, as can be seen in Figure 2, there is a persistent "component bias" in China's intra-East manufacturing trade. The share of parts and components in the PRC's total manufacturing imports from East Asia increased from 16 percent in 1992-93 to 46 percent in 2006-07. By contrast, on the import side, the regional share increased from 5.2 percent to 21.5 percent over the same period. Overall, these patterns are consistent with our earlier observation that China's rise in world trade has brought about a notable shift in the division of labor within regional production networks, with other countries in the region playing an increasing role in producing parts and components for the rapidly growing final assembly activities in China.

\section{Production networks and trade patterns}

We have already drawn attention to the importance of fragmentation-based trade in East Asia. We now examine the implications of this new form of international spe- 
Figure 2. Share of parts and components in China's manufacturing trade with East Asian countries, 1992-2007 (\%)

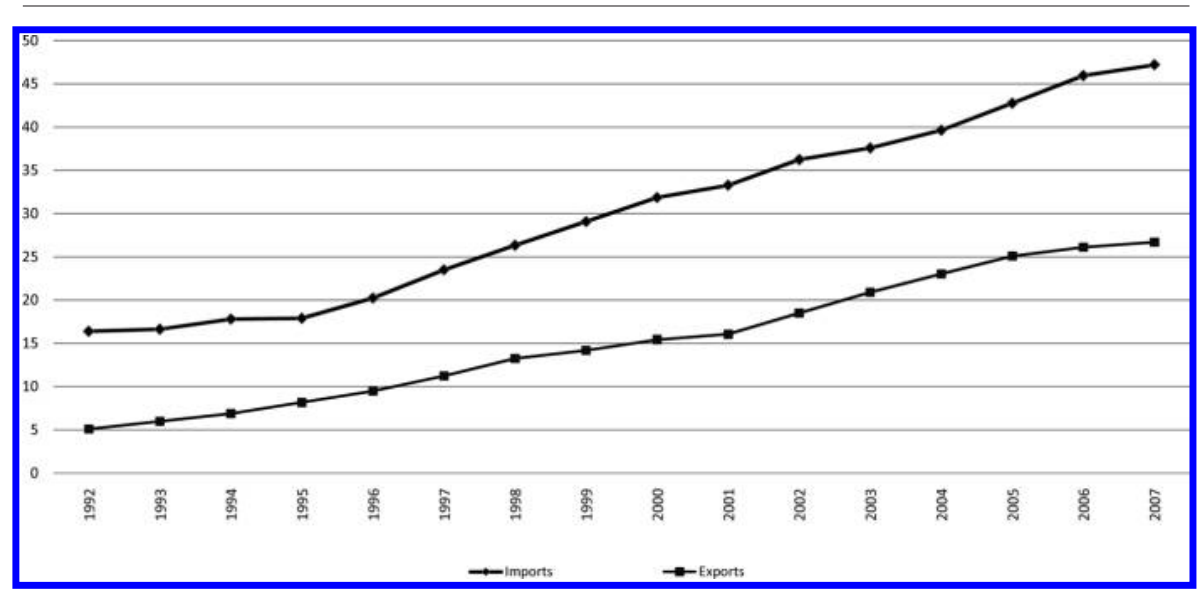

Source: Based on data compiled from UN Comtrade database.

cialization for the relative importance of intra-regional versus global economic integration.

There is a vast literature on what may be termed standard trade data analysis based on the traditional notion of horizontal specialization in which trade is an exchange of goods that are produced from start to finish in just one country. This literature unequivocally points to a persistent increase in intra-regional trade in East Asia, whether or not Japan is included, from about the early 1980s. ${ }^{8}$ This evidence figures prominently in the current regional debate concerning the establishment of regional trading arrangements covering some or all countries in East Asia. Another implication of the highly publicized trade integration in the region was the so-called decoupling thesis, which was a popular theme in Asian policy circles in the first decade of the new millennium until the onset of the recent financial crisis. ${ }^{9}$ This thesis held that East Asia had become a self-contained economic entity with the potential for maintaining its own growth dynamism independent of the economic outlook for the traditional developed market economies.

The earlier discussion on the emerging patterns of intra-regional component trade casts doubts on the validity of these inferences. We have seen that component trade has played a much more important role in trade expansion in East Asia compared to

8 See, for example, Drysdale and Garnaut (1997), Frankel and Wei (1997), and Park and Shin (2009).

9 See Yoshitomi (2007) and Park and Shin (2009) and the works cited therein. 
the rest of the world. Conventional trade flow analysis can yield an unbiased picture of regional economic integration only if component trade and final trade follow the same geographic patterns. If component trade has a distinct intra-regional bias, as one would reasonably anticipate in the context of growing network trade in the region, then the conventional trade flow analysis is bound to yield a misleading picture in regard to the relative importance of intra-regional trade versus global trade for growth dynamism in the region. This is because growth based on assembly activities depends on the demand for final goods, which in turn depends on extraregional growth.

Table 5 reports data on component intensity (percentage shares of parts and components) in bilateral flows of manufacturing trade. The data vividly show that parts and components accounts for a much larger share of intra-regional trade in East Asia compared to these countries world trade and trade with the EU and NAFTA. Moreover, the share of parts and components in total intra-regional imports is much larger than in exports and has increased at a faster rate. This reflects the fact that the region relies more on the rest of the world as a market for final goods than as a market for parts and components. Within East Asia, ASEAN countries stand out for the high share of parts and components in their intra-regional trade flows. The share of parts and components in total intra-regional exports in ASEAN countries increased from 34.6 percent in 1992-93 to 56.0 percent in 2006-07. On the import side, the increase was from 50.4 percent to 55.9 percent from 75.3 percent to 84.4 percent. According to country-level data (not reported here, for brevity), the share of parts and components in manufacturing exports and imports amounted to more than fourfifths in Singapore, Malaysia, and the Philippines, and over two-thirds in Thailand. Korea and Taiwan are also involved in sizeable trade in parts and components with other countries in the region.

Intra-regional trade shares estimated separately for total manufacturing trade, component trade, and final manufacturing trade (that is, total manufacturing trade less component trade) are reported in Table 6. The table covers trade in East Asia and three of its sub-regions, which relate to contemporary Asian policy debates on regional integration. Data for NAFTA and the EU are reported for comparative purposes. Estimates are given for total trade (imports + exports) as well as for exports and imports separately to illustrate possible asymmetry in trade patterns resulting from East Asia's increased engagement in fragmentation-based international exchange. Trade patterns depicted by the unadjusted (standard) trade data affirm the received view that Asia, in particular East Asia, has become increasingly integrated through merchandise trade. 
Table 5. Share of parts and components in bilateral trade flows, 1992-93 and 2006-07 (\%)

\begin{tabular}{|c|c|c|c|c|c|c|c|c|c|}
\hline Reporting region/country & & EA & Japan & DEA & PRC & ASEAN & NAFTA & EU15 & World \\
\hline \multicolumn{10}{|l|}{ (a) Exports } \\
\hline East Asia (EA) & $\begin{array}{l}1992-93 \\
2006-07\end{array}$ & $\begin{array}{l}23.6 \\
47.6\end{array}$ & $\begin{array}{l}13.9 \\
32.9\end{array}$ & $\begin{array}{l}24.9 \\
50.1\end{array}$ & $\begin{array}{l}18.5 \\
51.6\end{array}$ & $\begin{array}{l}32.1 \\
54.5\end{array}$ & $\begin{array}{l}21.1 \\
25.1\end{array}$ & $\begin{array}{l}17.7 \\
24.1\end{array}$ & $\begin{array}{l}20.2 \\
34.1\end{array}$ \\
\hline Japan & $\begin{array}{l}1992-93 \\
2006-07\end{array}$ & $\begin{array}{l}28.9 \\
42.0\end{array}$ & - & $\begin{array}{l}28.9 \\
42.0\end{array}$ & $\begin{array}{l}18.9 \\
41.5\end{array}$ & $\begin{array}{l}31.4 \\
47.9\end{array}$ & $\begin{array}{l}25.5 \\
31.5\end{array}$ & $\begin{array}{l}20.9 \\
30.4\end{array}$ & $\begin{array}{l}23.9 \\
34.4\end{array}$ \\
\hline $\begin{array}{l}\text { Developing East Asia } \\
\text { (DEA) }\end{array}$ & $\begin{array}{l}1992-93 \\
2006-07\end{array}$ & $\begin{array}{l}20.1 \\
48.1\end{array}$ & $\begin{array}{l}13.9 \\
33.4\end{array}$ & $\begin{array}{l}21.6 \\
53.9\end{array}$ & $\begin{array}{l}17.8 \\
49.5\end{array}$ & $\begin{array}{l}32.8 \\
65.2\end{array}$ & $\begin{array}{l}17.0 \\
22.7\end{array}$ & $\begin{array}{l}14.7 \\
21.6\end{array}$ & $\begin{array}{l}17.3 \\
34.0\end{array}$ \\
\hline China (PRC) & $\begin{array}{l}1992-93 \\
2006-07\end{array}$ & $\begin{array}{l}8.7 \\
36.2\end{array}$ & $\begin{array}{r}6.0 \\
25.2\end{array}$ & $\begin{array}{r}9.4 \\
40.6\end{array}$ & - & $\begin{array}{l}14.6 \\
49.1\end{array}$ & $\begin{array}{r}5.8 \\
17.1\end{array}$ & $\begin{array}{r}6.0 \\
16.3\end{array}$ & $\begin{array}{r}7.4 \\
25.6\end{array}$ \\
\hline Republic of Korea & $\begin{array}{l}1992-93 \\
2006-07\end{array}$ & $\begin{array}{l}19.2 \\
61.9\end{array}$ & $\begin{array}{l}15.6 \\
51.5\end{array}$ & $\begin{array}{l}21.0 \\
63.5\end{array}$ & $\begin{array}{r}9.5 \\
57.3\end{array}$ & $\begin{array}{l}25.6 \\
63.7\end{array}$ & $\begin{array}{l}20.6 \\
36.6\end{array}$ & $\begin{array}{l}16.3 \\
26.8\end{array}$ & $\begin{array}{l}18.1 \\
44.2\end{array}$ \\
\hline Taiwan & $\begin{array}{l}1992-93 \\
2006-07\end{array}$ & $\begin{array}{l}24.1 \\
51.5\end{array}$ & $\begin{array}{l}19.5 \\
59.0\end{array}$ & $\begin{array}{l}25.3 \\
50.5\end{array}$ & $\begin{array}{l}22.8 \\
39.5\end{array}$ & $\begin{array}{l}29.8 \\
61.2\end{array}$ & $\begin{array}{l}23.9 \\
35.0\end{array}$ & $\begin{array}{l}31.9 \\
37.6\end{array}$ & $\begin{array}{l}24.7 \\
44.2\end{array}$ \\
\hline $\begin{array}{l}\text { Association of Southeast } \\
\text { Asian Nations (ASEAN) }\end{array}$ & $\begin{array}{l}1992-93 \\
2006-07\end{array}$ & $\begin{array}{l}29.4 \\
58.2\end{array}$ & $\begin{array}{l}18.0 \\
39.9\end{array}$ & $\begin{array}{l}32.6 \\
61.4\end{array}$ & $\begin{array}{r}7.7 \\
64.0\end{array}$ & $\begin{array}{l}34.6 \\
56.0\end{array}$ & $\begin{array}{l}21.1 \\
32.1\end{array}$ & $\begin{array}{l}17.3 \\
33.9\end{array}$ & $\begin{array}{l}22.7 \\
44.2\end{array}$ \\
\hline $\begin{array}{l}\text { North American Free Trade } \\
\text { Area (NAFTA) }\end{array}$ & $\begin{array}{l}1992-93 \\
2006-07\end{array}$ & $\begin{array}{l}30.0 \\
46.7\end{array}$ & $\begin{array}{l}26.7 \\
36.5\end{array}$ & $\begin{array}{l}31.5 \\
49.8\end{array}$ & $\begin{array}{l}15.7 \\
34.8\end{array}$ & $\begin{array}{l}36.8 \\
67.9\end{array}$ & $\begin{array}{l}29.0 \\
28.8\end{array}$ & $\begin{array}{l}30.4 \\
30.6\end{array}$ & $\begin{array}{l}28.4 \\
31.2\end{array}$ \\
\hline European Union (EU 15) & $\begin{array}{l}1992-93 \\
2006-07 \\
\end{array}$ & $\begin{array}{l}17.4 \\
31.4\end{array}$ & $\begin{array}{l}10.0 \\
18.7\end{array}$ & $\begin{array}{l}20.5 \\
34.8\end{array}$ & $\begin{array}{l}20.0 \\
30.4\end{array}$ & $\begin{array}{l}24.3 \\
46.5\end{array}$ & $\begin{array}{l}23.1 \\
22.1\end{array}$ & $\begin{array}{l}18.4 \\
22.0\end{array}$ & $\begin{array}{l}18.3 \\
22.4\end{array}$ \\
\hline \multicolumn{10}{|l|}{ (b) Imports } \\
\hline East Asia (EA) & $\begin{array}{l}1992-93 \\
2006-07\end{array}$ & $\begin{array}{l}35.5 \\
51.7\end{array}$ & $\begin{array}{l}43.5 \\
48.8\end{array}$ & $\begin{array}{l}30.3 \\
52.8\end{array}$ & $\begin{array}{r}8.2 \\
34.8\end{array}$ & $\begin{array}{l}49.8 \\
68.3\end{array}$ & $\begin{array}{l}42.8 \\
54.7\end{array}$ & $\begin{array}{l}23.3 \\
33.1\end{array}$ & $\begin{array}{l}27.2 \\
42.1\end{array}$ \\
\hline Japan & $\begin{array}{l}1992-93 \\
2006-07\end{array}$ & $\begin{array}{l}19.3 \\
34.2\end{array}$ & - & $\begin{array}{l}19.3 \\
34.2\end{array}$ & $\begin{array}{r}5.2 \\
23.1\end{array}$ & $\begin{array}{l}28.1 \\
44.9\end{array}$ & $\begin{array}{l}35.2 \\
41.0\end{array}$ & $\begin{array}{l}12.3 \\
18.9\end{array}$ & $\begin{array}{l}19.3 \\
29.9\end{array}$ \\
\hline DEA & $\begin{array}{l}1992-93 \\
2006-07\end{array}$ & $\begin{array}{l}37.8 \\
55.5\end{array}$ & $\begin{array}{l}43.8 \\
47.7\end{array}$ & $\begin{array}{l}32.9 \\
59.5\end{array}$ & $\begin{array}{r}9.0 \\
43.2\end{array}$ & $\begin{array}{l}55.6 \\
74.3\end{array}$ & $\begin{array}{l}45.3 \\
40.3\end{array}$ & $\begin{array}{l}27.7 \\
31.7\end{array}$ & $\begin{array}{l}29.0 \\
44.2\end{array}$ \\
\hline PRC & $\begin{array}{l}1992-93 \\
2006-07\end{array}$ & $\begin{array}{l}24.6 \\
55.2\end{array}$ & $\begin{array}{l}25.0 \\
47.5\end{array}$ & $\begin{array}{l}23.7 \\
59.2\end{array}$ & - & $\begin{array}{l}11.5 \\
74.0\end{array}$ & $\begin{array}{l}19.7 \\
40.1\end{array}$ & $\begin{array}{l}23.5 \\
31.6\end{array}$ & $\begin{array}{l}20.4 \\
44.0\end{array}$ \\
\hline Republic of Korea & $\begin{array}{l}1992-93 \\
2006-07\end{array}$ & $\begin{array}{l}36.1 \\
33\end{array}$ & $\begin{array}{l}35.2 \\
26.6\end{array}$ & $\begin{array}{l}38.8 \\
38.1\end{array}$ & $\begin{array}{r}5.5 \\
26.1\end{array}$ & $\begin{array}{l}45.2 \\
55.7\end{array}$ & $\begin{array}{l}35.3 \\
38.9\end{array}$ & $\begin{array}{l}16.5 \\
22.9\end{array}$ & $\begin{array}{l}30.1 \\
31.9\end{array}$ \\
\hline Taiwan & $\begin{array}{l}1992-93 \\
2006-07\end{array}$ & $\begin{array}{l}37.2 \\
46.7\end{array}$ & $\begin{array}{l}36.5 \\
33.8\end{array}$ & $\begin{array}{l}39.4 \\
58.3\end{array}$ & $\begin{array}{r}6.6 \\
44.1\end{array}$ & $\begin{array}{l}44.4 \\
68.8\end{array}$ & $\begin{array}{l}29.9 \\
40.2\end{array}$ & $\begin{array}{l}19.8 \\
28.0\end{array}$ & $\begin{array}{l}29.5 \\
38.9\end{array}$ \\
\hline ASEAN & $\begin{array}{l}1992-93 \\
2006-07\end{array}$ & $\begin{array}{l}41.6 \\
50.3\end{array}$ & $\begin{array}{l}40.6 \\
47.2\end{array}$ & $\begin{array}{l}42.6 \\
51.4\end{array}$ & $\begin{array}{l}11.9 \\
40.1\end{array}$ & $\begin{array}{l}50.4 \\
55.9\end{array}$ & $\begin{array}{l}45.2 \\
67.5\end{array}$ & $\begin{array}{l}28.0 \\
41.7\end{array}$ & $\begin{array}{l}36.0 \\
47.9\end{array}$ \\
\hline NAFTA & $\begin{array}{l}1992-93 \\
2006-07\end{array}$ & $\begin{array}{l}36.5 \\
29.4\end{array}$ & $\begin{array}{l}44.1 \\
39.3\end{array}$ & $\begin{array}{l}29.5 \\
26.0\end{array}$ & $\begin{array}{r}6.3 \\
17.7\end{array}$ & $\begin{array}{l}41.2 \\
40.5\end{array}$ & $\begin{array}{l}47.6 \\
36.3\end{array}$ & $\begin{array}{l}35.5 \\
25.1\end{array}$ & $\begin{array}{l}37.4 \\
28.8\end{array}$ \\
\hline EU15 & $\begin{array}{l}1992-93 \\
2006-07\end{array}$ & $\begin{array}{l}22.2 \\
25.0\end{array}$ & $\begin{array}{l}26.1 \\
33.6\end{array}$ & $\begin{array}{l}18.5 \\
22.8\end{array}$ & $\begin{array}{r}4.7 \\
14.9\end{array}$ & $\begin{array}{l}24.3 \\
37.9\end{array}$ & $\begin{array}{l}36.0 \\
34.1\end{array}$ & $\begin{array}{l}20.5 \\
22.1\end{array}$ & $\begin{array}{l}21.2 \\
23.4\end{array}$ \\
\hline
\end{tabular}

Source: Compiled from UN Comtrade database.

Note: $-=$ Not applicable.

In 2006-07, intra-regional trade accounted for 55.1 percent of total manufacturing trade in East Asia, up from 53.2 percent in 1992-93. The level of intra-regional trade in East Asia was higher than that of NAFTA throughout this period and was rapidly approaching the level of the EU. For DEA (Asia excluding Japan) and ASEAN+3, the ratios are lower than the aggregate regional figure, but they have increased at a much faster rate. The intra-regional trade share of ASEAN has been much lower compared to the other two sub-regions. This asymmetry in intra-regional trade in East Asia reflects the unique nature of the involvement of Japan and the PRC in regional production networks. From about the late 1980s Japan's manufacturing trade 
Table 6. Intra-regional shares of manufacturing trade: Total, parts and components, and final trade, $1992-93$ and $2006-07^{\text {a }}(\%)$

\begin{tabular}{|c|c|c|c|c|c|c|}
\hline (a) Total trade & East Asia & $\begin{array}{l}\text { Developing } \\
\text { East Asia }\end{array}$ & ASEAN $+3^{b}$ & ASEAN & NAFTA & EU15 \\
\hline $\begin{array}{l}\text { Exports } \\
1992-93 \\
2006-07\end{array}$ & $\begin{array}{l}47.2 \\
43.9\end{array}$ & $\begin{array}{l}38.2 \\
33.4\end{array}$ & $\begin{array}{l}15.3 \\
21.9\end{array}$ & $\begin{array}{l}20.7 \\
18.4\end{array}$ & $\begin{array}{l}44.4 \\
48.1\end{array}$ & $\begin{array}{l}61.2 \\
56.9\end{array}$ \\
\hline $\begin{array}{l}\text { Imports } \\
1992-93 \\
2006-07\end{array}$ & $\begin{array}{l}58.2 \\
64.4\end{array}$ & $\begin{array}{l}34.9 \\
46.7\end{array}$ & $\begin{array}{l}43.0 \\
49.3\end{array}$ & $\begin{array}{l}15.5 \\
20.8\end{array}$ & $\begin{array}{l}36.3 \\
32.0\end{array}$ & $\begin{array}{l}64.1 \\
57.9\end{array}$ \\
\hline $\begin{array}{l}\text { Trade (exports + } \\
\text { 1992-93 } \\
2006-07\end{array}$ & $\begin{array}{l}\text { orts) } \\
53.2 \\
55.1\end{array}$ & $\begin{array}{l}36.5 \\
40.0\end{array}$ & $\begin{array}{l}27.0 \\
30.4\end{array}$ & $\begin{array}{l}17.8 \\
20.1\end{array}$ & $\begin{array}{l}39.9 \\
38.4\end{array}$ & $\begin{array}{l}62.6 \\
57.4\end{array}$ \\
\hline (b) Parts and co & onents & & & & & \\
\hline $\begin{array}{l}\text { Exports } \\
1992-93 \\
2006-07\end{array}$ & $\begin{array}{l}50.2 \\
61.1\end{array}$ & $\begin{array}{l}42.6 \\
53.9\end{array}$ & $\begin{array}{l}33.7 \\
35.3\end{array}$ & $\begin{array}{l}30.3 \\
25.4\end{array}$ & $\begin{array}{l}43.5 \\
46.9\end{array}$ & $\begin{array}{l}62.3 \\
55.9\end{array}$ \\
\hline $\begin{array}{l}\text { Imports } \\
1992-93 \\
2006-07\end{array}$ & $\begin{array}{l}65.9 \\
66.9\end{array}$ & $\begin{array}{l}35.3 \\
50.9\end{array}$ & $\begin{array}{l}39.6 \\
47.8\end{array}$ & $\begin{array}{l}20.2 \\
22.9\end{array}$ & $\begin{array}{l}39.5 \\
39.9\end{array}$ & $\begin{array}{l}58.0 \\
55.2\end{array}$ \\
\hline $\begin{array}{l}\text { Trade } \\
1992-93 \\
2006-07\end{array}$ & $\begin{array}{l}57.0 \\
62.9\end{array}$ & $\begin{array}{l}38.7 \\
52.1\end{array}$ & $\begin{array}{l}35.4 \\
40.2\end{array}$ & $\begin{array}{l}24.2 \\
23.1\end{array}$ & $\begin{array}{l}41.4 \\
43.2\end{array}$ & $\begin{array}{l}60.1 \\
55.5\end{array}$ \\
\hline (c) Final goods & & & & & & \\
\hline $\begin{array}{l}\text { Exports } \\
1992-93 \\
2006-07\end{array}$ & $\begin{array}{l}46.0 \\
36.9\end{array}$ & $\begin{array}{l}36.8 \\
28.3\end{array}$ & $\begin{array}{l}11.4 \\
17.0\end{array}$ & $\begin{array}{l}16.1 \\
15.9\end{array}$ & $\begin{array}{l}44.7 \\
48.7\end{array}$ & $\begin{array}{l}60.9 \\
57.0\end{array}$ \\
\hline $\begin{array}{l}\text { Imports } \\
1992-93 \\
2006-07\end{array}$ & $\begin{array}{l}55.4 \\
63.0\end{array}$ & $\begin{array}{l}34.7 \\
42.8\end{array}$ & $\begin{array}{l}43.4 \\
50.2\end{array}$ & $\begin{array}{l}12.9 \\
20.6\end{array}$ & $\begin{array}{l}35.3 \\
30.2\end{array}$ & $\begin{array}{l}65.6 \\
58.5\end{array}$ \\
\hline $\begin{array}{l}\text { Trade } \\
\text { 1992-93 } \\
2006-07\end{array}$ & $\begin{array}{l}50.3 \\
44.4\end{array}$ & $\begin{array}{l}35.7 \\
34.0\end{array}$ & $\begin{array}{l}25.4 \\
29.1\end{array}$ & $\begin{array}{l}14.3 \\
18.0\end{array}$ & $\begin{array}{l}39.4 \\
37.3\end{array}$ & $\begin{array}{l}63.2 \\
57.7\end{array}$ \\
\hline
\end{tabular}

Source: Compiled from UN Comtrade database, and Trade Data CD-ROM, Council for Economic Planning and Development, Taipei (for data on Taiwan).

Notes: a. Intra-regional trade shares have been calculated excluding bilateral flows between China and Hong Kong.

b. ASEAN + Japan + Korea + China.

c. Total (reported) trade (a) 2 parts and components (b).

relations with the rest of East Asia have been predominantly in the form of using the region as an assembly base for meeting demand in the region and, more importantly, for exporting to the rest of the world (Athukorala and Yamashita 2008). The emergence of the PRC as a leading assembly center within regional production networks since the early 1990s further amplified this trade asymmetry. That is, the PRC is importing parts and components from the other East Asia countries to assemble final products, which are predominantly destined for markets in the rest of the world (Athukorala 2009).

However, the picture changes significantly when parts and components are netted out: the share of intra-East-Asian final trade (total trade-parts and components) in 
2006-07 was 46.4 percent, down from 50.3 percent in 1992-93. The estimates based on unadjusted data and data on final trade are vastly different for East Asia, particularly for DEA and ASEAN. Both the level of trade in the given years and the change over time in intra-regional trade shares are significantly lower for estimates based on final trade. Interestingly, we do not observe such a difference in estimates for NAFTA and the EU.

The intra-regional shares calculated separately for imports and exports clearly illustrate the risk of making inferences about regional trade integration based on total (imports + exports) data. There is a notable asymmetry in the degree of regional trade integration in East Asia. Unlike in the EU and NAFTA, in East Asia the increase over time in the intra-regional trade ratio (both measured using unadjusted data and data for final trade) has emanated largely from a rapid increase in intraregional imports as the expansion in intra-regional exports has been consistently slower. The dependence of East Asia (and East Asian country sub-groups) on extraregional markets, in particular those in NAFTA and the EU, for export-led growth is far greater than is revealed by the standard intra-regional trade ratios commonly used in the debate on regional economic integration. For instance, in 2006-07 only 43.9 percent of total East Asian manufacturing exports were absorbed within the region, compared to an intra-regional share of 64.4 percent in total manufacturing imports. For DEA, the comparable figures were 33.4 percent and 46.7 percent, respectively. This asymmetry is clearly seen across all sub-regions within East Asia. The asymmetry between intra-regional shares of imports and exports is therefore much sharper when parts and components are netted out. This is understandable given the heavy component bias in Asian intra-regional trade and the multiple bordercrossing of parts and components within regional production networks. On the export side, the intra-regional share of final goods declined continuously from 46 percent in 1995 to 37 percent in 2007, whereas the intra-regional import share increased from 56 percent to 63 percent between these two time points. The observed asymmetry in intra-regional trade in East Asia reflects the unique nature of the involvement of Japan and the PRC in regional production networks.

In sum, these data support the hypothesis that where fragmentation-based trade is expanding rapidly, the standard trade flow analysis can lead to misleading inferences regarding the process of economic integration through trade. When data on assembly trade are excluded from trade flows, these estimates suggest that extraregional trade is much more important than intra-regional trade for continued growth in East Asia, whether or not Japan is included. Thus, the rising importance of product fragmentation seems to have strengthened the case for a global approach to trade and investment policymaking rather than a regional one. 
Figure 3. Growth of merchandise trade: East Asia, Developing East Asia, and ASEAN, Jan. 2008-Nov. 2009 (y-o-y, \%)

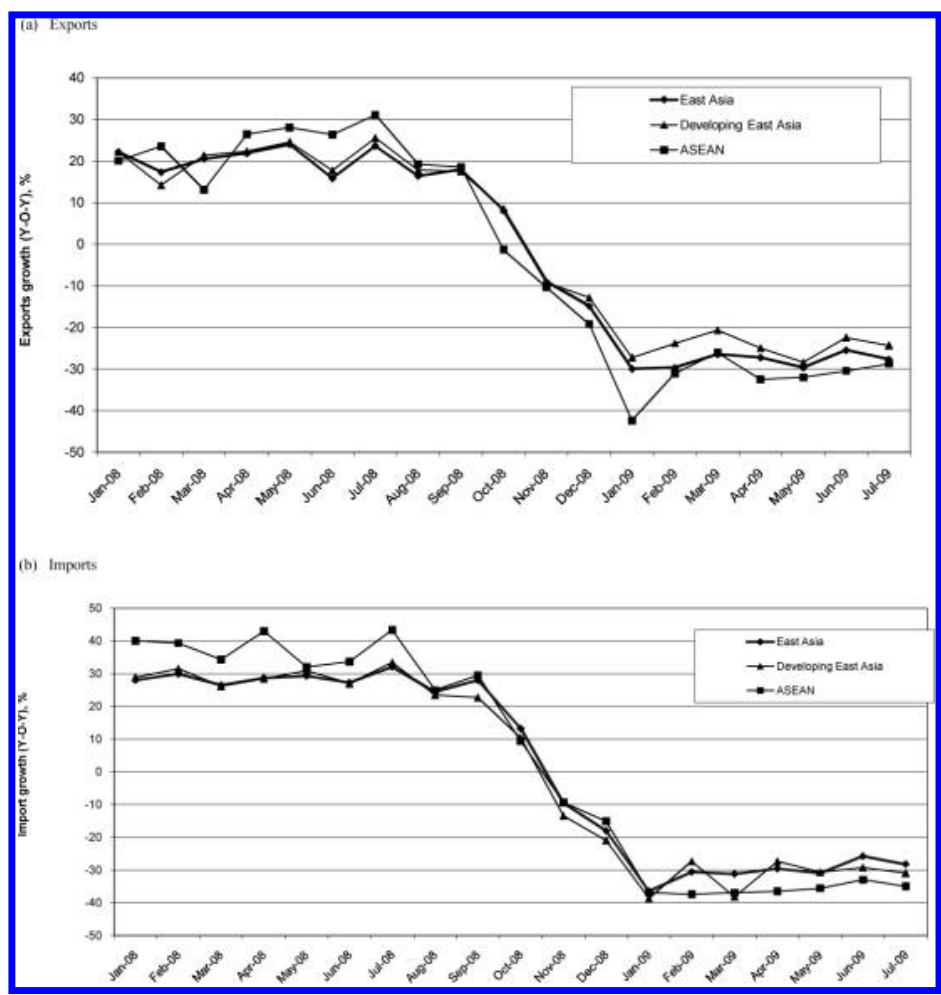

Source: Based on data compiled from CEIM database.

\section{Production networks and trade flows in the crisis}

A striking feature of the global economy following the onset of the in late 2008 global financial crisis has been the precipitous drop in global trade at a faster rate than during the Great Depression (Krugman 2009; Almunia et al. 2010). From April 2008 to June 2009 world trade contracted by about 20 percent, which amounted to almost the total contraction in world trade during the first 30 months of the Great Depression (starting in April 1929). ${ }^{10}$ Interestingly, the trade contraction experienced by the East Asian countries during this period was even greater than the contraction in total world trade (Figure 3, Table 7).

10 Numbers derived from Figure 5 in Almunia et al. (2010). 
Table 7. East Asia: Growth of total merchandise exports and imports, 2007:Q1-2009:Q3 (y-o-y percent change)

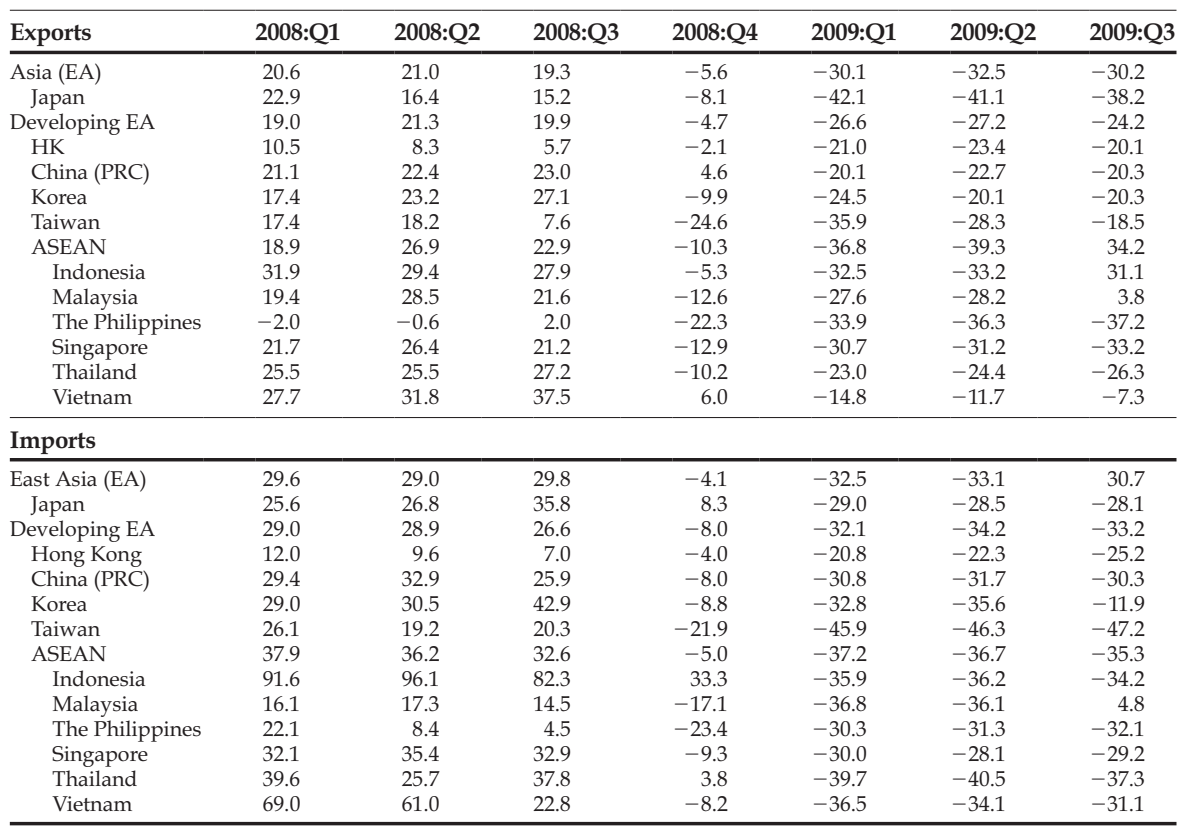

Source: Compiled from CIEM database.

Note: Growth rates calculated using current US\$ values.

Krugman (2009) points to the increased vertical integration of global production (the rise of globe production sharing) as a possible explanation for the surprisingly large trade contraction in the present crisis compared to the Great Depression. Vertical integration of production implies that a given degree of contraction in demand for a final (assembled) product has ramifications over trade flows between the many countries involved in the production chain. Also, demand for parts and components is susceptible to rapid stock adjustment by producers compared to final goods. Given that global production sharing is much more important for trade expansion in East Asia, this explanation also seems relevant for East Asia's greater trade contraction compared to overall trade contraction at the global level. However, a number of other factors are also relevant for explaining the larger contraction in trade volume in the current crisis. These include the much larger contraction of trade credit, a greater share of consumer durables in contemporary world trade compared to the 1930s, and the effect of recent advances in communication technology on inventory cycle and just-in-time procurement practices. The current state of data availability does not permit us to systematically delineate the impact of production 
Table 8. China: Growth of total merchandise exports and imports by trading partner countries, 2007:Q1-2009:Q4 (y-o-y parentage change, current US\$)

\begin{tabular}{|c|c|c|c|c|c|c|c|c|}
\hline (a) Exports & 2008:Q1 & 2008:Q2 & 2008:Q3 & 2008:Q4 & 2009:Q1 & 2009:Q2 & 2009:Q3 & 2009:Q4 ${ }^{\mathrm{a}}$ \\
\hline East Asia (EA) & 23.7 & 25.1 & 28.2 & 4.5 & -23.4 & -24.2 & -18.0 & 8.2 \\
\hline Japan & 12.1 & 18.0 & 18.1 & 7.9 & -16.7 & -23.8 & -16.3 & -6.7 \\
\hline Developing EA & 31.2 & 29.2 & 33.9 & 2.7 & -24.1 & -24.5 & -28.7 & 7.5 \\
\hline Korea & 33.1 & 38.3 & 52.9 & 7.5 & -29.2 & -36.6 & -35.0 & -3.0 \\
\hline Taiwan & 15.4 & 21.1 & 17.3 & -10.4 & -34.5 & -38.8 & -21.4 & 20.1 \\
\hline Hong Kong & 10.8 & 6.5 & 11.0 & -9.9 & -24.0 & -21.6 & -16.6 & 12.2 \\
\hline ASEAN & 34.2 & 26.0 & 27.4 & 2.8 & -22.6 & -16.8 & -9.6 & 23.0 \\
\hline Indonesia & 33.2 & 41.5 & 54.8 & 20.2 & -26.4 & -21.0 & -24.0 & 21.3 \\
\hline Malaysia & 33.3 & 28.2 & 20.8 & 7.1 & -23.9 & -12.2 & -9.1 & 9.2 \\
\hline The Philippines & 30.4 & 22.8 & 34.5 & 1.3 & -11.8 & -18.7 & -8.5 & 18.6 \\
\hline Singapore & 15.3 & 5.9 & 17.1 & -0.6 & -17.1 & -12.3 & -16.2 & 21.4 \\
\hline Thailand & 37.2 & 42.1 & 38.3 & 5.9 & -27.3 & -29.6 & -14.3 & 21.1 \\
\hline Vietnam & 88.8 & 45.1 & 16.0 & -11.1 & -30.0 & -15.9 & 36.3 & 58.9 \\
\hline United States & 5.4 & 12.2 & 15.3 & 0.7 & -15.4 & -18.5 & -16.7 & 1.4 \\
\hline $\mathrm{EU}$ & 25.0 & 29.7 & 23.5 & 4.1 & -22.6 & -26.6 & -23.6 & -4.2 \\
\hline Total export & 16.3 & 19.0 & 20.2 & 0.9 & -21.1 & -23.5 & -20.3 & 7.2 \\
\hline \multicolumn{9}{|l|}{ (b) Imports } \\
\hline East Asia & 18.8 & 24.1 & 13.2 & -18.1 & -33.7 & -23.1 & -12.5 & 30.2 \\
\hline Japan & 17.0 & 23.7 & 18.7 & -5.0 & -29.8 & -21.4 & -13.4 & 15.6 \\
\hline Developing EA & 19.6 & 24.3 & 10.8 & -23.6 & -35.3 & -23.8 & -12.1 & 37.7 \\
\hline Korea & 14.9 & 25.0 & 14.8 & -18.5 & -26.6 & -18.8 & -10.2 & 33.6 \\
\hline Taiwan & 24.5 & 24.2 & 5.0 & -33.3 & -43.9 & -29.9 & -14.9 & 43.8 \\
\hline Hong Kong & 26.0 & -2.5 & 11.0 & -21.4 & -49.1 & -32.9 & -33.3 & -7.7 \\
\hline ASEAN & 19.9 & 23.8 & 12.7 & -18.9 & -33.8 & -22.1 & -8.9 & 12.2 \\
\hline Indonesia & 31.7 & 30.3 & 17.3 & -13.5 & -38.0 & -18.4 & -6.3 & 69.6 \\
\hline Malaysia & 18.4 & 29.5 & 22.4 & -16.1 & -25.0 & -17.0 & -3.5 & 60.3 \\
\hline The Philippines & 12.7 & 5.7 & -23.2 & -48.6 & -61.3 & -51.7 & -30.3 & 17.6 \\
\hline Singapore & 6.7 & 35.5 & 27.4 & -9.3 & -23.7 & -28.2 & -11.9 & 27.2 \\
\hline Thailand & 26.0 & 22.9 & 15.8 & -5.6 & -29.2 & -6.6 & -0.9 & 29.7 \\
\hline Vietnam & 64.3 & 19.0 & 69.4 & 6.8 & -7.9 & 23.6 & -8.3 & 47.7 \\
\hline United States & 29.7 & 23.0 & 15.7 & 3.7 & -17.7 & -13.1 & -6.4 & 19.3 \\
\hline EU & 25.9 & 33.0 & 22.7 & 2.3 & -14.7 & -11.2 & -2.2 & 14.9 \\
\hline Total imports & 21.2 & 25.0 & 15.1 & -12.2 & -28.3 & -19.6 & -11.9 & 10.2 \\
\hline
\end{tabular}

Source: Compiled from CIEM database.

Note: Growth rates calculated using current US\$ values.

a. Average for October and November.

sharing on trade contraction while appropriately controlling for these other possible factors. Instead, this section puts together some readily available data that have some bearing on this issue to set the stage for further analysis.

All major East Asian countries (including China, which was expected by the decoupling enthusiasts to cushion the rest of East Asia against a global economic collapse) experienced a precipitous trade contraction from about the last quarter of 2008 (Table 8). The remarkably synchronized nature of the trade contraction across countries in the region, both in imports and exports, is generally consistent with the close trade ties among the East Asian countries forged within regional production networks and the unique role of the region within global production networks.

Among the East Asian countries Japan has been the worst hit by far. A large share of Japan's exports consists of capital goods and high-end durable consumer goods, 
such as cars and electrical machinery and machine tools and their parts and components. Exports of capital goods and high-end consumer durables are heavily concentrated in the United States and other developed-country markets and are therefore directly exposed to the global economic decline. On the other hand, contrary to the predictions of the decoupling enthusiasts, Japan's growing exports to China have been indirectly affected by declining final (assembled) exports from China (Fukao and Yuan 2009). The degree of export contraction suffered by Taiwan and Korea has been smaller compared to Japan but, on average, notably higher compared to the other East Asian countries. As in the case of Japan, growing exports to China do not seem to have provided a cushion against collapse in world demand for these two countries. The relatively lower degree of export contractions experienced by Korea, Taiwan, and the second-tier exporting countries in the region compared to Japan could possibly reflect consumer preferences for price-competitive low-end products in the crisis context.

An inspection of growth rates of exports of individual East Asian countries by destination provides no support for the view that East Asian economies have become less susceptible to the world-wide trade contraction because of regional growth dynamism. ${ }^{11}$ Intra-East Asia trade flows have in general contracted at a faster rate compared to these countries exports to the United States and EU.

Exports to China from most countries in the region have contracted at a much faster rate compared to their imports from China, perhaps an indication of destocking of parts and components by Chinese firms given the gloomy outlook for exports (Table 8). China's imports from Japan, Korea, and Taiwan have shrunk more rapidly (at an average rate of 23.5 percent) than imports from other countries. This is not surprising, given the dominant role played by the former countries in the supply of parts and components to ICT assembly activities in China, which are heavily exposed to contractions in import demand in the United States and other developed countries. Overall China's imports from countries in the region intra-regional imports have contracted at a much faster rate compared to her imports from the United States and EU.

Data on export growth by major commodity category for Chinese imports and exports are summarized in Table 9. A notable pattern is the relatively sharper contraction in the category of machinery exports (in which network trade is heavily concentrated) compared to other product categories, in particular traditional laborintensive products (textile and garments, footwear, and other miscellaneous

11 This inference is based on monthly exports data extracted from the CIEM database (not reported here for brevity). 
Table 9. China: Growth of merchandise exports and imports by commodity category, 2008:Q1- 2009:Q3 (y-o-y percent change, current US\$)

\begin{tabular}{|c|c|c|c|c|c|c|c|}
\hline (a) Exports & 2008:Q1 & 2008:Q2 & 2008:Q3 & 2008:Q4 & 2009:Q1 & 2009:Q2 & 2009:Q3 \\
\hline Total exports & 16.3 & 19.0 & 20.2 & 0.9 & -21.1 & -23.5 & -20.3 \\
\hline Primary & 16.3 & 24.9 & 29.9 & 8.6 & -17.9 & -13.6 & -14.2 \\
\hline Manufacturing & 21.2 & 23.8 & 22.0 & 2.6 & -20.7 & -18.2 & -17.2 \\
\hline $\begin{array}{l}\text { Products of the chemical or allied } \\
\text { industries }\end{array}$ & 48.5 & 54.0 & 42.2 & 3.1 & -25.2 & -24.9 & -23.4 \\
\hline $\begin{array}{l}\text { Plastics and articles thereof, rubber } \\
\text { and articles }\end{array}$ & 13.8 & 10.1 & 16.1 & 10.7 & -21.1 & -17.1 & -17.3 \\
\hline Textiles and textile articles & 22.5 & 5.3 & 4.1 & 8.0 & -11.4 & 2.6 & 4.2 \\
\hline Footwear, headgear, umbrellas, etc & 14.7 & 14.4 & 19.7 & 21.3 & -1.3 & 7.2 & 8.2 \\
\hline Base metals \& articles of base metal & 23.3 & 18.5 & 26.4 & 22.0 & -9.0 & -1.5 & -4.3 \\
\hline $\begin{array}{l}\text { Machinery and mechanical appliances, } \\
\text { etc (ME) }\end{array}$ & 15.9 & -15.7 & 20.9 & 4.3 & -31.6 & -38.8 & -42.1 \\
\hline Electronics & 6.2 & 12.5 & 61.5 & 17.2 & -33.5 & -36.5 & -37.3 \\
\hline Electrical machinery and equipment & 20.3 & 27.0 & 20.4 & -1.1 & -21.5 & -19.5 & -20.2 \\
\hline Miscellaneous manufactured articles & 41.5 & 39.0 & 31.7 & 9.1 & -17.0 & -19.7 & -6.2 \\
\hline (b) Imports & 2008:Q1 & 2008:Q2 & 2008:Q3 & 2008:Q4 & 2009:Q1 & 2009:Q2 & 2009:Q3 \\
\hline Total imports & 21.2 & 25.0 & 15.1 & -12.2 & -28.3 & -19.6 & -11.9 \\
\hline Primary & 73.5 & 74.9 & 72.5 & 5.2 & -40.7 & -35.3 & -27.2 \\
\hline Manufacturing & 16.3 & 19.1 & 11.4 & -12.1 & -26.2 & -21.1 & -19.2 \\
\hline $\begin{array}{l}\text { Products of the chemical or allied } \\
\text { industries }\end{array}$ & 19.6 & 23.5 & 19.6 & -10.5 & -23.9 & -18.2 & -16.3 \\
\hline $\begin{array}{l}\text { Plastics and articles thereof, rubber } \\
\text { and articles }\end{array}$ & 16.3 & 22.5 & 22.7 & -15.6 & -29.2 & -20.1 & 15.2 \\
\hline Textiles and textile articles & 6.3 & 2.7 & -3.4 & -9.2 & -22.8 & -22.8 & -23.2 \\
\hline Footwear, headgear, umbrellas, etc & 47.5 & 47.7 & 24.8 & 12.6 & -2.8 & -18.7 & -22.2 \\
\hline Base metals \& articles of base metal & 14.1 & 5.8 & 8.3 & -15.0 & -26.3 & -16.9 & -2.7 \\
\hline $\begin{array}{l}\text { Machinery and mechanical appliances, } \\
\text { etc (me) }\end{array}$ & 11.7 & 18.0 & 9.8 & -10.7 & -24.1 & -17.9 & -8.2 \\
\hline Electronics & 16.3 & 19.9 & 15.0 & -1.0 & -19.8 & -19.5 & -3.2 \\
\hline Electrical machinery and equipment & 9.5 & 17.1 & 7.4 & -15.2 & -26.3 & -17.4 & -6.7 \\
\hline Miscellaneous manufactured articles & 11.6 & 20.8 & 1.4 & -8.1 & -5.4 & 1.6 & 2.2 \\
\hline
\end{tabular}

Source: Compiled from CEIM database.

manufactures). Exports belonging to this commodity category, in particular ICT products and consumer electronics, are also predominantly consumer durables which, as already noted, are generally more susceptible to income contraction. In traditional labor-intensive products, developing country producers have the ability to perform better purely on the basis of cost competitiveness even in a context of depressed demand.

Data on the growth of manufacturing imports to the United States are summarized in Table 10. A common pattern observable across the ten source countries covered is that component imports have generally contracted at a faster rate compared with total imports and final goods imports. This pattern is consistent with the view that in face of contraction in world demand, stock adjustment takes place at a faster rate in intermediate goods compared to final goods. The data also show that the rate of contraction in final imports from the PRC has been much smaller compared to the dramatic contraction in imports from Japan. This perhaps reflects the fact that under depressed market conditions, consumers tends to substitute low-end products for high-end products. 
Table 10. Growth manufacturing imports to the United States, 2008:Q1-2009:Q3 (y-o-y \%)

\begin{tabular}{|c|c|c|c|c|c|c|c|}
\hline & 2008:Q1 & 2008:Q2 & 2008:Q3 & 2008:Q4 & 2009:Q1 & 2009:Q2 & 2009:Q3 \\
\hline \multicolumn{8}{|l|}{ East Asia (EA) } \\
\hline Total manufacturing & 2.0 & 4.1 & 4.9 & -6.8 & -22.3 & -24.2 & -22.0 \\
\hline Parts and components & -2.5 & 3.9 & 2.6 & -14.3 & -29.1 & -29.3 & -23.9 \\
\hline Assembly & 6.0 & 8.5 & 4.8 & -13.6 & -30.6 & -25.9 & -21.6 \\
\hline Total network trade ${ }^{a}$ & 2.6 & 6.7 & 4.0 & -13.8 & -30.0 & -27.2 & -22.4 \\
\hline \multicolumn{8}{|l|}{ Developing EA } \\
\hline Total manufacturing & 1.1 & 4.5 & 7.5 & -3.9 & -15.4 & -18.7 & -19.0 \\
\hline Parts and components & -4.3 & 4.6 & 4.2 & -12.8 & -25.2 & -26.1 & -22.2 \\
\hline Assembly & 5.3 & 9.8 & 10.0 & -9.5 & -17.6 & -15.5 & -16.1 \\
\hline Total network trade ${ }^{a}$ & 1.4 & 7.8 & 7.9 & -10.6 & -20.5 & -19.4 & -18.3 \\
\hline \multicolumn{8}{|c|}{ Association of Southeast Asian Nations (ASEAN) } \\
\hline Total manufacturing & 0.4 & 1.8 & -2.3 & -15.2 & -26.5 & -24.1 & -16.2 \\
\hline Parts and components & -6.5 & 4.3 & -2.6 & -21.2 & -32.5 & -31.1 & -15.8 \\
\hline Assembly & 3.0 & 4.8 & -6.3 & -25.1 & -39.6 & -36.5 & -26.5 \\
\hline Total network trade ${ }^{a}$ & -2.1 & 4.6 & -4.7 & -23.5 & -36.5 & -34.2 & -22.1 \\
\hline \multicolumn{8}{|l|}{ Japan } \\
\hline Total manufacturing & 4.6 & 2.9 & -4.1 & -16.6 & -42.3 & -42.5 & -33.5 \\
\hline Parts and components & 1.6 & 2.1 & -1.0 & -17.7 & -37.1 & -37.4 & -28.5 \\
\hline Assembly & 7.5 & 6.0 & -6.7 & -23.2 & -55.0 & -49.6 & -35.2 \\
\hline Total network trade $\mathrm{a}^{\mathrm{a}}$ & 5.3 & 4.5 & -4.7 & -21.4 & -49.0 & -45.3 & -33.0 \\
\hline \multicolumn{8}{|l|}{ Republic of Korea } \\
\hline Total manufacturing & 0.4 & 7.6 & 11.5 & -0.2 & -15.1 & -23.1 & -25.1 \\
\hline Parts and components & -11.3 & 0.2 & 1.9 & -14.4 & -32.1 & -33.3 & -26.2 \\
\hline Assembly & 4.3 & 13.9 & 14.4 & -2.1 & -9.4 & -12.6 & -17.7 \\
\hline Total network trade $\mathrm{e}^{\mathrm{a}}$ & -1.2 & 9.3 & 10.0 & -5.9 & -16.5 & -19.0 & -20.4 \\
\hline \multicolumn{8}{|l|}{ Taiwan } \\
\hline Total manufacturing & 5.8 & 2.8 & 4.1 & -10.3 & -28.5 & -32.3 & -22.9 \\
\hline Parts and components & 11.8 & 12.1 & 3.9 & -16.4 & -30.8 & -33.1 & -21.2 \\
\hline Assembly & 11.0 & 6.4 & 12.5 & -7.5 & -31.4 & -32.0 & -21.5 \\
\hline Total network trade $\mathrm{e}^{\mathrm{a}}$ & 11.0 & 9.3 & 7.8 & -12.4 & -31.1 & -32.6 & -21.3 \\
\hline \multicolumn{8}{|c|}{ People's Republic of China (PRC) } \\
\hline Total manufacturing & 1.3 & 5.3 & 10.1 & -0.6 & -11.2 & -16.0 & -18.4 \\
\hline Parts and components & -1.6 & 5.9 & 7.7 & -8.7 & -20.2 & -22.3 & -23.6 \\
\hline Assembly & 7.0 & 10.9 & 14.9 & -6.1 & -11.7 & -9.3 & -12.8 \\
\hline Total network trade ${ }^{a}$ & 3.7 & 9.0 & 12.4 & -7.0 & -14.8 & -14.0 & -16.5 \\
\hline \multicolumn{8}{|l|}{ Mexico } \\
\hline Total manufacturing & 2.8 & 3.9 & -4.2 & -11.8 & -25.2 & -27.6 & -17.0 \\
\hline Parts and components & -3.6 & -4.3 & -7.6 & -15.1 & -31.0 & -32.7 & -17.7 \\
\hline Assembly & 10.1 & 12.0 & -6.6 & -11.8 & -21.6 & -23.8 & -11.3 \\
\hline Total network trade ${ }^{a}$ & 3.3 & 4.1 & -7.1 & -13.2 & -26.0 & -27.8 & -14.1 \\
\hline \multicolumn{8}{|l|}{ World } \\
\hline Total manufacturing & 2.9 & 4.5 & 3.5 & -9.2 & -25.4 & -29.3 & -25.1 \\
\hline Parts and components & -0.3 & 1.8 & 0.0 & -13.7 & -28.4 & -31.7 & -24.8 \\
\hline Assembly & 4.5 & 7.2 & -0.1 & -16.5 & -31.9 & -30.1 & -22.6 \\
\hline Total network trade ${ }^{\mathrm{a}}$ & 2.3 & 4.8 & 0.0 & -15.4 & -30.4 & -30.8 & -23.5 \\
\hline
\end{tabular}

Source: Compiled from U.S. International Trade Commission on-line database.

a. Parts and components plus final assembly.

\section{Concluding remarks}

Global production sharing has become an integral part of the economic landscape of East Asia. Trade within global production networks has been expanding more rapidly than conventional final-good trade. The degree of dependence on this new form of international specialization is proportionately larger in East Asia (particularly ASEAN) than in North America and Europe. The rapid integration of the PRC into regional production networks is a critically important recent development in the 
international fragmentation of production. The PRC's imports of parts and components from ASEAN countries and other DEA countries have grown rapidly, in line with the equally rapid expansion of manufacturing exports from the PRC to extraregional markets, mostly in North America and Europe. The migration of some production processes within vertically integrated high-tech industries to the PRC has opened up opportunities for producing original, equipment-manufactured goods and back-to-office service operations in other countries. The PRC's emergence as a major trading power and an investment location has not been a zero-sum proposition from the perspective of the region. Rather, it seems to have added further dynamism to region-wide operations of multinational enterprises.

Global production sharing has certainly played a pivotal role in the continued dynamism of East Asia and its increasing intra-regional economic interdependence. This does not, however, mean that the process has contributed to lessening the region's dependence on the global economy. The high intra-regional trade shares reported in recent studies largely reflect rapidly expanding intra-regional trade in components. There is no evidence of rapid intra-regional trade integration in final products. In fact, the region's growth based on vertical specialization depends inexorably on its extra-regional trade in final goods, and this dependence has increased over the years. Extra-regional trade is likely to remain the engine of growth for the region in the foreseeable future. This inference is basically consistent with the behavior of trade flows following the onset of the global financial crisis. The remarkably synchronized nature of trade contraction across countries in the region is generally consistent with close trade ties among East Asian countries forged within regional production networks. In addition, the PRC failed to provide a cushion against this export contraction as postulated by the decoupling thesis.

The rise of global production sharing has strengthened the case for a global, rather than a regional, approach to trade and investment policymaking. Given the global orientation of the region's economies, we question whether there would be any significant positive pay-off from current efforts to promote regional cooperation, unless they recognize the principle of open regionalism. With both the current Doha Round and Asia-Pacific Economic Cooperation apparently floundering and directionless, this is one of the major multilateral policy challenges of our time.

In any case, it is doubtful whether the free-trade agreement (FTA) approach to trade liberalization is feasible in a context where global production networks are rapidly expanding and seamlessly encompassing many industries and countries. In reality, the trade effect of any FTA would depend very much on the nature of the rules of origin (ROOs) built into it. The trade-distorting effects of ROOs are presumably more detrimental to network trade than to conventional final-goods trade, because 
of the inherent difficulties in defining the product for duty exemption and because of the transaction costs associated with the bureaucratic supervision of the amount of value-added in production coming from various sources. Formulating ROOs for network-related trade is a rather complicated business. The conventional valueadded criterion is not virtually applicable to this trade because the products involved are low-value-added by their very nature. The only viable option is to pursue so-called change-in-tariff-lines-based ROOs, but this leads to insurmountable administrative problems because trade in electrical and electronics goods, and their related components, belong to the same tariff codes at the HS-6 digit level, which is the normal base for designing these type of ROOs. Moreover, the process of global production sharing is characterized by the continuous emergence of new products. Given the obvious administrative problems involved in revising ROOs in tandem, the emergence of new products naturally opens up room for unnecessary administrative delays and the tweaking of rules as a means of disguised protection.

\section{References}

Abrenica, Joy V. 1998. The Asian Automotive Industry: Assessing the Roles of State and Market in the Age of Global Competition. Asian-Pacific Economic Literature 12(1):12-26.

Almunia, Miguel, Austin Benetrix, Barry Eichengreen, Kevin H. O’Rourke, and Gisela Rua. 2010. From Great Depression to Great Credit Crisis: Similarities, Differences and Lessons. Economic Policy April:219-265.

Athukorala, Prema-chandra. 2005. Product Fragmentation and Trade Patterns in East Asia. Asian Economic Papers 4(3):1-27.

Athukorala, Prema-chandra. 2008. Singapore and ASEAN in the New Regional Division of Labour. Sinqapore Economic Review 53(3):479-508.

Athukorala, Prema-chandra. 2009. The Rise of China and East Asian Export Performance: Is the Crowding-out Fear Warranted? World Economy 32(2):234-266.

Athukorala, Prema-chandra. 2010. Production Networks and Trade Patterns in East Asia: Regionalization or Globalization? ADB Working Paper Series on Regional Economic Integration No. 56. Manila: Asian Development Bank.

Athukorala, Prema-chandra, and Nobuaki Yamashita. 2008. Patterns and Determinants of Production Fragmentation in World Manufacturing Trade. In Globalization, Regionalism and Economic Interdependence, edited by Filippo do Mauro, Stephanie Dees, and Warwick McKibbin, pp. 45-72. Cambridge: Cambridge University Press.

Brown, Clair, and Greg Linden. 2005. Offshoring in the Semiconductor Industry: A Historical Perspective. In The Brookings Trade Forum 2005: Offshoring White-Collar Work: The Issues and Implications, edited by Lael Brainard and Susan M. Collins, pp. 270-333. Washington, DC: Brooking Institution Press.

Dean, Judith, K. C. Fung, and Zhi Wang. 2007. Measuring the Vertical Specialization in Chinese Trade. USITC Working Paper 2007-01-A. Washington, DC: US International Trade Commission. 
Drysdale, Peter, and Ross Garnaut. 1997. The Pacific: An Application of a General Theory of Economic Integration. In Pacific Dynamism and the International Economic System, edited by C. Fred Bergsten and Marcus Noland, pp. 183-224. Washington, DC: Institute for International Economics.

Drucker, Peter. 1977. The Rise of Production Sharing. The Wall Street Journal. March 15, p. 8.

Feenstra, Robert C. 2008. Offshoring in the Global Economy (The Ohlin Lectures 2008). Stockholm School of Economics.

Feenstra, Robert C., Wen Hai, Wing Thye Woo, and Shunli Yao. 1999. Discrepancies in International Trade Data: An Application to China-Hong Kong entrepôt trade. American Economic Review 89(2):338-343.

Frankel, Jeffrey A., and Shang-Jin Wei. 1997. The New Regionalism and Asia: Impact and Policy Options. In The Global Trading System and Developing Asia, edited by Arvind Panagariya,

M. G. Quibria, and Narhari Rao, pp. 83-130. Oxford: Oxford University Press.

Fukao, Kyoji, and Tangjun Yuan. 2009. Why Is Japan So Heavily Affected by the Global Economic Crisis? Available at www.voxeu.org

Gorg, H. 2000. Fragmentation and Trade: U.S. Inward Processing Trade in the EU.

Weltwirtschaftliches Archiv 136(3):403-422.

Helleiner, Gerand K. 1973. Manufactured Exports from Less-Developed Countries and Multinational Firms. Economic Journal 83(329):21-47.

Hummels, David. 2007. Transport Costs and International Trade in the Second Era of Globalization. Lournal of Economic Perspectives 21(2):131-154.

Hummels, David, Jun Ishii, and Kei-Mu Yi. 2001. The Nature and Growth of Vertical Specialization in World Trade. Lournal of International Economics 54(1):75-96.

Kimura, Fukunari. 2006. International Production and Distribution Networks in East Asia: 18 Facts, Mechanics, and Policy Implications. Asian Economic Policy Review 1(1):346-347.

Klier, Thomas, and James Rubenstein. 2008. Who Really Made Your Car? Restructuring and Geographic Change in the Auto Industry. Michigan: W.E. Upjohn Institute for Employment Research.

Krugman, Paul R. 2008. Trade and Wages, Reconsidered. Brookings Papers on Economic Activity 1: Macroeconomics, pp. 103-138.

Krugman, Paul. 2009. The Return of Depression Economics. Linoel Robbins Lectures (presentation and the summary by Geoff Riley and Paul Krugman at the London School of Economics). Available at http://cep.lse.ac.uk/_new/events/special_post.asp

Ng, Francis, and Alexander Yeats. 2003. Major Trade Trends in East Asia: What Are Their Implications for Regional Cooperation and Growth? Policy Research Working Paper No. 3084. Washington, DC: World Bank.

Park, Yung Chul, and Kwanho Shin. 2009. Economic Integration and Changes in the Business Cycle in East Asia: Is the Region Decoupling from the Rest of the World? Asian Economic Papers 8(1):107-140.

Sharpton, Michael. 1975. International Subcontracting. Oxford Economic Papers 27(1):94-135. 
USITC (United State International Trade Commission). 1999. Production Sharing: Use of U.S. Components and Material in Foreign Assembly Operations, 1995-1998. USITC Publication 3265. Washington, DC: USITC.

Wong, Hpo Kam. 2007. The Remaking of Singapore's High-Tech Enterprise System. In Making IT: The Rise of Asian in High Tech, edited by Henry S. Rowen, Marguerite G. Hancock, and Lilliam F. Miller, pp. 123-174. Stanford, CA: Stanford University Press.

Yeats, Alexander. 2001. Just How Big Is Global Production Sharing? In Fragmentation: New Production Patterns in the World Economy, edited by Seven Arndt and Henryk Kierzkowski, pp. 108-143. New York: Oxford University Press.

Yoshitomi, Masaru. 2007. Global Imbalances and East Asian Monetary Cooperation. In Towards and East Asian Exchange Rate Regime, edited by Duck-Koo Chung and Barry Eichengreen, pp. 22-48. Washington, DC: Brookings Institution Press. 